\title{
TURNING THE SPOTLIGHT ON CLASS REPRESENTATIVES - EMPIRICAL INSIGHTS FROM DOWN UNDER
}

\author{
Jane Caruana \\ Vince Morabito*
}

Ten months before Ontario became the first Canadian common law province to authorise American-style class actions, class actions became available in the Federal Court of Australia. In these two countries and in the United States, the named plaintiffs, commonly referred to as class representatives, are the only claimants formally in charge of the litigation, on the plaintiff side, whilst the outcome of class actions binds not only them and their opponents but also the claimants that they represent, the absent class members. And yet, to date, there have been no comprehensive studies of class representatives in these three countries. The aim of this article is to partly address this significant lacuna in the international legal literature by providing the findings of an empirical study, that the authors have undertaken, of the persons that acted as class representatives in the class actions that were filed in the first 17 years of the operation of the class action procedure in the Federal Court of Australia. It is hoped that this article will prompt Canadian scholars to undertake similar studies with respect to Canadian class representatives.

Dix mois avant que l'Ontario devienne la première province de common law canadienne à autoriser les recours collectifs à l'américaine, la Cour fédérale d'Australie autorisait ceux-ci. Dans ces deux pays, ainsi qu'aux États-Unis, les demandeurs nommés, communément appelés représentants, sont les seuls demandeurs formellement mêlés au litige du côté de la partie

Jane is a Research Assistant and Vince is a Professor in the Department of Business Law and Taxation at Monash University (Melbourne). The research presented in this article was funded by: (a) an Australian Research Council Discovery Project grant (DP0984648); and (b) research donations received from Freehills (major sponsor) and other entities including the Australasian Institute of Judicial Administration. We would also like to thank Justice Bernard Murphy of the Federal Court of Australia; Neil Francey (member of the NSW and Queensland Bars); Lachlan Armstrong (member of the Victorian and NSW Bars); Ben Slade, Brooke Dellavedova, Rebecca Gilsenan, Jason Geisker, Barry Lipp, Irina Lubomirska, Ronald Koo and Tina Vecchio (Maurice Blackburn Lawyers); Odette McDonald, Ken Fowlie, James Higgins, Vicky Antzoulatos, Peter Long, Steven Lewis and Ben Phi (Slater \& Gordon); Ron Willemsen and Stuart Walter (Macpherson + Kelley Lawyers); Peter Humphries (Duncan Basheer Hannon); Simon Morrison (Shine Lawyers); Michael Duffy (Monash University); and Professor Peter Cashman (Sydney University) for providing the authors with a wealth of invaluable information regarding many of the class representatives explored in this article. We also wish to thank the two anonymous referees for their extremely useful insights and suggestions. 
demanderesse, tandis que l'issue des recours collectifs lie non seulement les représentants et leurs adversaires, mais aussi les demandeurs qu'ils représentent, c'est-à-dire les personnes inscrites au recours collectif qui sont absentes. Pourtant, il n'y a eu à ce jour aucune étude approfondie sur ces représentants de groupes dans ces trois pays. L'objet du présent article est de combler en partie cette importante lacune dans la littérature juridique internationale en fournissant les conclusions d'une étude empirique effectuée par les auteurs et portant sur les représentants dans le cadre des recours collectifs introduits dans les 17 premières années du régime des recours collectifs devant la Cour fédérale d'Australie. Il est à espérer que le présent article incitera les chercheurs canadiens à entreprendre de telles études en ce qui concerne les représentants de groupes canadiens.

\section{INTRODUCTION}

He sues, not for himself alone, but as representative of a class comprising all who are similarly situated. The interests of all in the redress of the wrongs are taken into his hands, dependent upon his diligence, wisdom and integrity. ... He is a self-chosen representative and a volunteer champion.

By putting themselves forward as representative plaintiffs, they warrant that they have the willingness and resources to prosecute the claim. If they do not have the stomach for it, they should not take on the job.

Class actions represent a significant exception to the general rule that one cannot be bound by the outcome of a legal proceeding unless one is a named party in the litigation in question. ${ }^{3}$ The two comments quoted above - made by the United States Supreme Court and Justice Strathy of Ontario's Supreme Court of Justice, respectively - also highlight the crucial role that named plaintiffs, frequently referred to as class representatives, play in class actions. ${ }^{4}$ Once they make the

Cohen v Beneficial Industrial Loan Corp, 337 US 541, at 549 (1949).

Turon v Abbott Laboratories Ltd, 2011 ONSC 4343, at para 24, Strathy J.

3 See e.g. Hansberry v Lee, 311 US 32 at 40-41 (1940); Alberta Law Reform Institute, Class

Actions, (Final Report no 85: December, 2000) at para 57 online: Alberta Law Reform Institute < http://www.law.u-alberta.ca/alri/docs/fr085.pdf>; Martin v Wilks, 490 US 755 at 762 n2 (1989); Fantl v Transamerica Life Canada [2008] OJ No 1536 at para 51 (ONSC) [Fantl v

Transamerica], Perell J; McCarthy v Canadian Red Cross Society (2001) 8 CPC $\left(5^{\text {th }}\right) 349$ at para 21 (ONSC); and Research Corp v Pfister Associated Growers, Inc, 301 F Supp 497 at 501 (DC Ill 1969). It is thus not surprising that several Canadian courts have described class action litigation as "sui generis litigation": see e.g. Heron v Guidant Corp [2007] OJ No 3823 at para 10 (ONSC), Cullity J; and Fantl v Transamerica Life Canada (2009) 95 OR (3d) 767 at 776 (ONCA) [Fantl].

4 Whilst the relevant comment by the US Supreme Court, set out at the beginning of the article, was made in the context of shareholder derivative actions a number of subsequent American courts have cited this comment in the context of outlining the responsibilities of class representatives. 
decision to file a class action they become the only members, of the relevant class/group of similarly situated claimants, that are formally responsible for the carriage, burdens and costs of the litigation.

The origins of the modern class action device may be traced back to the amendments that were made in 1966 to Rule 23 of the United States Federal Rules of Civil Procedure. The most innovative and emulated feature of this 1966 US class action model was the opt out device. In simple terms, the opt out device enables persons to bring class actions on behalf of claimants without seeking the consent of, or naming, the claimants in question. These class members will be bound by the outcome of the class action litigation unless they avail themselves of an opportunity that is normally extended to them during the course of the litigation to exit or opt out of the proceeding. ${ }^{6}$

Opt out class action regimes were first introduced in Canada in 1978 in Quebec. Ontario followed suit in 1993 and there are currently comprehensive class action regimes in the Federal Court of Canada and in all Canadian provinces other than the province of Prince Edward Island. ${ }^{7}$ In March 1992 the Federal Court of Australia became Australia's first court to authorise and regulate class actions, through the enactment of Part IVA of the Federal Court of Australia Act 1976 (Cth) (Part IVA). ${ }^{8}$ Class action regimes almost identical to the federal regime came into operation in the Supreme Court of Victoria (in January 2000) ${ }^{9}$ and in the Supreme Court of New South Wales (in March 2011). ${ }^{10}$

Despite the fact that class actions constitute an extremely important and controversial component of the civil justice landscape in each of these three countries and that, as noted above, the operation of these class action regimes is generally dependent on the willingness of one or more persons with legal grievances $^{11}$ to assume the challenging and rather unique role of class

See e.g. In re Quintus Sec Litig, 148 F Supp 2d 967 at 970 (ND Cal, 2001); and Armour v Network Assocs Inc, 171 F Supp 2d 1044 at 1048 (ND Cal, 2001).

5 See Matthews v SPI Electricity Pty Ltd; SPI Electricity Pty Ltd v Utility Services Corporation Ltd (Ruling No 1) [2011] VSC 167 at paras 48 and 54, J Forrest J [SPI]; Scott v TD Waterhouse Investor Services (Canada) Inc (2001) 94 BCLR (3d) 320 at 347 (SC); Lambert v Guidant Corp [2009] OJ No 1910 at para 136 (ONSC), Cullity J [Lambert]; Kidd v Canada Life Assurance Co 2011 ONSC 6324 at para 59, Perell J; Fantl, ibid at 777; and Cohen v The State of Victoria \& Ors (No 2) [2011] VSC 165 at para 35, J Forrest J [Cohen].

6 This opportunity is extended to class members "because individuals pursuing their self-interest may have very good reasons not to be bound by a resolution of the class case. They may want to preserve their rights to pursue individual actions; they may not feel that they have been wronged; or that they may have other available avenues of redress which they perceive to be superior than the class proceeding": Mangan v Inco Ltd (1998) 38 OR (3d) 703 at 715, Poupore J. See also Jarra Creek Central Packing Shed Pty Ltd v Amcor Limited [2008] FCA 575 at para 16, Tamberlin J; and Elizabeth Chamblee Burch, "Optimal Lead Plaintiffs" (2011) 64 Vand L Rev 1109 at 1132.

7 See generally Mathew Good, “Access to Justice, Judicial Economy, and Behaviour Modification: Exploring the Goals of Canadian Class Actions” (2009) 47 Alb L Rev 185 at $189 \mathrm{fn} 4$.

8 Federal Court of Australia Act 1976 (Cth) [Part IVA].

$9 \quad$ Supreme Court Act 1986 (Vic), Part 4A.

10 Civil Procedure Act 2005 (NSW), Part 10.

11 See e.g. Stone $v$ Wellington (County) Board of Education (1999) $29 \mathrm{CPC}\left(4^{\text {th }}\right) 320$ at para 10 where Ontario's Court of Appeal drew attention to "the clear legislative requirement that the representative plaintiff be anchored in the proceeding as a class member, not simply a nominee with no stake in the potential outcome”. See also French v Investia Financial Services Inc 2012 
representatives, no study of the personal characteristics of these important players in the class action arena may be found in the legal literature.

The authors commenced in January 2009 the first ever empirical study of the operation of Part IVA. This study encompasses a review of the court files, media reports and data and information provided to the authors by lawyers and litigation funders with respect to all the class actions that were filed in the Federal Court of Australia in the first 17 years of the operation of Part IVA, that is, from 4 March 1992 to 3 March 2009 ("study period").

The aim of this article is to employ the data and findings from this empirical study to shed some light regarding some of the fundamental characteristics possessed by these largely mysterious protagonists. This will be achieved by asking a number of basic questions such as: were most of them natural persons or corporate entities? Did any of them file more than one class action? What prompted individuals to assume this challenging role? What do plaintiff lawyers look for in class representatives? What was their gender? What was their age? Did they reside in the same jurisdiction where the Part IVA proceeding was filed? What was their marital status? What was their employment status? Were any of them under a disability?

The empirical data collected on class representatives, with respect to the issues outlined in the preceding paragraph, is then compared with similar data concerning Australia's overall population to determine the extent to which these class representatives may be regarded as "representative" of the Australian community. This comparison will reveal whether several categories or classes of individuals (classified pursuant to criteria such as gender, age, residence, marital status, occupational status and disabilities) are under-represented or over-represented in the representation of claimants in class action litigation. Possible reasons for this under-representation or over-representation, as the case may be, will also be explored. In light of the general lack of studies with respect to the personal characteristics of plaintiffs generally, this study will provide data and findings that will also be of benefit to those interested in acquiring some understanding of the types of claimants who seek to enforce their legal rights through the filing of legal proceedings.

Another important reason for undertaking this comparison between noncorporate class representatives and Australia's general population stems from the firm belief, held by a number of class action defendants and their legal representatives, that plaintiff lawyers regularly appoint or choose, as class representatives, "persons of straw". ${ }^{12}$ The incentives for pursuing this strategy or practice result from the fact that Part IVA (and indeed most class action statutes

ONSC 1150 at para 93, Shaughnessy J [French]. In some Canadian jurisdictions, like British Columbia, trial judges are authorised to "certify a person who is not a member of the class as the representative plaintiff for the class proceeding only if it is necessary to do so in order to avoid a substantial injustice to the class": Class Proceedings Act, RSBC 1996, c 50, s 2(4).

12 See e.g. S Stuart Clark \& Christina Harris, "Multi-Plaintiff Litigation in Australia - A

Comparative Perspective" (2001) 11 Duke J Comp \& Int'1 L 289 at 303; and Damian Grave, Ken Adams \& Jason Betts, Class Actions in Australia, 2d ed (Sydney: Lawbook Co, 2012;) at 735. It is thus fascinating to note that a defendant in a class action filed in Ontario sought to support its submission that the proposed class representatives were unsuitable as class representatives by drawing attention to, among other things, the prosperity of these representatives: 1176560 Ontario Limited $v$ The Great Atlantic \& Pacific Company of Canada Limited (2002) 62 OR (3d) 535 at 545 (ONSC), Winkler J. See also French, ibid at para 95. 
and rules) expressly provides that class representatives are the only claimants against whom cost orders may be made in class action litigation. ${ }^{13}$ Thus, class action defendants ${ }^{14}$ may turn only to class representatives in order to recoup some of the costs that they incurred in successfully defending themselves. A major consequence flowing from the frequent implementation of this strategy, of having persons of straw as class representatives, is that class representatives come exclusively or predominantly from limited and "precarious" sectors of our society. This comparison of the average class representative in Part IVA proceedings with the average Australian will thus provide objective data and insights as to the likely existence and prevalence of this practice. The evaluation of the data presented in this article will also provide a general picture of the types of claims that have been advanced, and thus the types of claimants that have been represented, in Part IVA proceedings.

\section{NATURAL PERSONS versus LEGAL PERSONS}

\section{A. Who may commence a Part IVA proceeding?}

There is no restriction imposed by the terms of Part IVA as to the categories of claimants that may commence a Part IVA proceeding. As long as three threshold ${ }^{15}$ requirements are satisfied, ${ }^{16}$ a Part IVA proceeding may be commenced by any person that has individual standing to sue the defendants in question. ${ }^{17}$ Thus, socalled ideological plaintiffs may not bring a Part IVA proceeding, subject to one minor exception. The exception relates to the fact that it is not necessary for the class representative to have been adversely affected by the impugned conduct; it is only necessary that they have individual standing to sue.

Thus, where the standing is, for instance, conferred by Acts of Parliament - that regulate particular areas, industries, services or products - on specified regulatory entities and/or members of the general public, a Part IVA proceeding may be commenced by the entities and persons in question without the need to show that they have been individually affected by the conduct that is being challenged in the proceeding. ${ }^{18}$ This state of affairs has enabled entities such as Australia's consumer "watchdog", the Australian Competition and Consumer Commission [ACCC], to file Part IVA proceedings on behalf of aggrieved consumers. As shown in Table 1 below, the ACCC has done so on six occasions.

Part IVA does not employ a certification regime. As a result, there is no onus on the class representatives to demonstrate, at the outset of the proceeding, that the

13 Part IVA, supra note 8 at s 43(1A).

14 In the Federal Court of Australia, the parties are referred to as applicants and respondents but in this article the more conventional terms - plaintiffs and defendants - are employed.

15 See Wong v Silkfield Pty Ltd (1999) 165 ALR 373 at 381, Gleeson CJ, McHugh, Gummow, Kirby and Callinan JJ [Wong]; and Philip Morris (Australia) Ltd v Nixon (2000) 170 ALR 487 at 514, Sackville J.

16 The three requirements are as follows: (a) seven or more persons who have claims against the same person; (b) the claims of all those persons must be in respect of, or arise out of, the same, similar or related circumstances; and (c) the claims of all those persons must give rise to a substantial issue of law or fact (Part IVA, s 33C(1)).

17 Part IVA, supra note 8 at ss 33C and 33D.

18 See generally Vince Morabito, "Ideological Plaintiffs and Class Actions - An Australian Perspective” (2001) 34 UBC L Rev 459. 
three threshold requirements have been satisfied. But those facing class actions ${ }^{19}$ may apply to the court to have the proceeding discontinued as a Part IVA proceeding on the basis that: (a) one or more of the three threshold requirements have not been adhered to; and/or (b) it is appropriate to exercise one of the powers that are conferred on trial judges to terminate in certain circumstances, as Part IVA proceedings, proceedings that have satisfied each of these three requirements. ${ }^{20}$

\section{B. General Data}

We identified a total of 250 Part IVA proceedings that were commenced in the Federal Court during the study period. In these 250 cases there were a total of 438 class representatives. ${ }^{21}$ This may be regarded as a gross figure due to the fact that it was arrived at by simply adding together the total number of class representatives in each of the 250 class actions, regardless of whether any of the class representatives assumed that role in more than one Part IVA proceeding. As explained below, there have, in fact, been a significant number of "repeat class representatives".

The figure of 438 class representatives includes what may be termed as "appeal only class representatives", that is, those who were class representatives only for the purpose of filing an appeal against a judgment handed down in the course of a Part IVA proceeding. We discovered ten of these class representatives. The filing of appeals by class members, on behalf of the class, has been made possible by Part IVA's s 33ZC (6). This section provides that where the class representative or sub-group representative does not file an appeal (from a judgment that relates to issues common to the claims of class members or of sub-group members) within the time provided for instituting an appeal, another member of the class or subgroup may, within a further 21 days, bring an appeal as representing the class members or sub-group members, as the case may be.

In addition to these 438 class representatives, there were also a total of 32 persons/entities that were named plaintiffs in Part IVA proceedings but did not represent any class members. That is to say, they only brought their individual claims. This occurred in 21 Part IVA proceedings and in 16 of them the non-Part IVA plaintiffs were trade unions. It is fascinating to note that this scenario of having, as a single action, a class action and an individual action was criticised in 2002 by Justice Epstein of the Ontario Superior Court of Justice on the basis that:

A joinder of a class action with an individual claim is not compatible with the advancement of the objectives of class

19 The terms "Part IVA proceedings" and "class actions" will be used interchangeably throughout the article.

20 Part IVA, supra note 8 at ss 33L, 33M and 33N. See generally Vince Morabito, "The Federal Court of Australia's Power to Terminate Properly Instituted Class Actions" (2004) 42 Osgoode Hall LJ 473.

21 This figure includes all those persons and entities that were class representatives in Part IVA proceedings at any time during the course of the litigation. Thus, it encompasses not only those who were class representatives at the time the Part IVA proceedings were filed but also those who were appointed as class representatives at any time after the proceedings were commenced. 
proceedings. Certainly joinder of an individual action with a class action is not consistent with the objectives of behaviour modification or access to justice. Depending on the facts of the particular case, joinder may also interfere with the type of judicial economy contemplated by class proceedings. In fact, joinder may unnecessarily complicate the class proceeding. ${ }^{23}$

\section{Categories of class representatives}

It is evident from Table 1 below that a large majority of those who acted as class representatives in Part IVA proceedings commenced in the study period were individuals. $^{24}$ There were 373 such class representatives representing over $85 \%$ of all of the class representatives identified in the study period. One or more individuals were class representatives in $216(86 \%)$ of all the Part IVA proceedings filed in the study period.

\section{Table 1: Categories of class representatives in Part IVA proceedings}

\begin{tabular}{|l|l|}
\hline Categories of class representatives & Total \\
\hline Individuals & 373 \\
\hline Companies & 53 \\
\hline ACCC & 6 \\
\hline Trade unions & 4 \\
\hline Local government council & 1 \\
\hline Unincorporated association & 1 \\
\hline
\end{tabular}

Table 2 divides the first seventeen years of the operation of Part IVA into four equal periods of 4 years and 3 months. It allows the identification of some interesting trends with respect to the types of class representatives that have instituted Part IVA proceedings.

\section{Table 2: Categories of class representatives over four quarters}

\begin{tabular}{|l|l|l|l|l|}
\hline & $\begin{array}{l}\text { First } \\
\text { quarter } \\
\text { (from 4 } \\
\text { March 1992 } \\
\text { to 3 June } \\
\mathbf{1 9 9 6 )}\end{array}$ & $\begin{array}{l}\text { Second quarter } \\
\text { from 4 June } \\
\text { 1996 to 3 } \\
\text { September 2000) }\end{array}$ & $\begin{array}{l}\text { Third quarter } \\
\text { (from 4 } \\
\text { September 2000 } \\
\text { to 3 December } \\
\mathbf{2 0 0 4}\end{array}$ & $\begin{array}{l}\text { Fourth quarter } \\
\text { (from 4 } \\
\text { December 2004 } \\
\text { to 3 March } \\
\text { 2009) }\end{array}$ \\
\hline Individuals & 68 & 171 & 73 & 61 \\
\hline Companies & 7 & 18 & 10 & 18 \\
\hline
\end{tabular}

23 Obonsawin v Canada [2002] OJ No 2502 at para 23 (ONSC). Compare Simpson et al $v$ Ontario, 1997 OTC LEXIS 3381 at para 1, Hockin J where, out of 11 named plaintiffs, only the first plaintiff represented the class.

24 A similar scenario exists in Canada: see Jasminka Kalajdzic, "Cultural Dimensions of Group Litigation - Canada", National Report for the International Association of Procedural Law's Civil Procedure in Cross-cultural Dialogue at Moscow, Russia, September 2012) at 3, online: XVth World Conference of the International Association of Procedural Law < http://www.osgoode.yorku.ca/iapl2012/>). In relation to US securities class actions, it was recently noted that "groups comprised solely of individuals represent the class around thirty percent of the time": Burch, supra note 6 at 1120. 


\begin{tabular}{|l|l|l|l|l|}
\hline ACCC & 1 & 4 & 1 & 0 \\
\hline Trade unions & 0 & 2 & 1 & 1 \\
\hline $\begin{array}{l}\text { Local } \\
\text { government } \\
\text { council }\end{array}$ & 0 & 1 & 0 & 0 \\
\hline $\begin{array}{l}\text { Unincorporated } \\
\text { association }\end{array}$ & 1 & 0 & 0 & 0 \\
\hline $\begin{array}{l}\text { All class } \\
\text { representatives }\end{array}$ & $\mathbf{7 7}$ & $\mathbf{1 9 6}$ & $\mathbf{8 5}$ & $\mathbf{8 0}$ \\
\hline
\end{tabular}

It is evident from the data tabled above that the proportion of corporate class representatives increased slightly over the first three quarters of the study period. In the first quarter of the study period there were only 7 corporate class representatives out of a total of 77, making up only $9.09 \%$ of all class representatives in that period. In the second quarter, there were $18(9.18 \%)$ companies out of a total of 196 class representatives. In the third quarter, there were $10(11.76 \%)$ companies out of 85 class representatives. During the fourth quarter, however, there was a noticeably sharper increase in the proportion of corporate class representatives vis-à-vis all other class representatives. As can be seen from the table above, there were 18 companies out of a total of 80 class representatives, constituting over $22 \%$ of all class representatives in proceedings commenced during that period.

Why was there a markedly larger increase in the proportion of companies assuming the role of class representative in the final quarter of the study period? An examination of the most common types of substantive claims that were advanced in class actions instituted in this period (and in the previous three quarters) may provide a possible explanation.

Table 3: Types of substantive claims over four quarters

\begin{tabular}{|l|l|l|l|l|}
\hline Type of Claim & $\begin{array}{l}\text { First quarter } \\
\text { (from 4 March } \\
\text { 1992 to 3 June } \\
\text { 1996) }\end{array}$ & $\begin{array}{l}\text { Second quarter } \\
\text { from 4 June } \\
\text { 1996 to 3 } \\
\text { September } \\
\text { 2000) }\end{array}$ & $\begin{array}{l}\text { Third quarter } \\
\text { (from 4 } \\
\text { September 2000 } \\
\text { to 3 December } \\
\text { 2004) }\end{array}$ & $\begin{array}{l}\text { Fourth quarter } \\
\text { (from 4 } \\
\text { December } \\
\text { 2004 to 3 March } \\
\text { 2009) }\end{array}$ \\
\hline $\begin{array}{l}\text { Product liability } \\
\text { (defective } \\
\text { goods and } \\
\text { services; mass } \\
\text { torts) }\end{array}$ & 5 & 39 & 6 & 2 \\
\hline Industrial & 1 & 17 & 0 & \\
\hline Migration & 12 & 17 & 0 & 5 \\
\hline $\begin{array}{l}\text { Shareholder } \\
\text { actions }\end{array}$ & 2 & 1 & 7 & 0 \\
\hline $\begin{array}{l}\text { Consumer } \\
\text { protection }\end{array}$ & 3 & 8 & 3 & 15 \\
\hline $\begin{array}{l}\text { Investment } \\
\text { schemes }\end{array}$ & 0 & 2 & 10 & 10 \\
\hline $\begin{array}{l}\text { Investment } \\
\text { advice } \\
\text { (professional } \\
\text { advisers) }\end{array}$ & 0 & 0 & 0 & \\
\hline
\end{tabular}




\begin{tabular}{|c|c|c|c|c|}
\hline $\begin{array}{l}\text { Loans/guara- } \\
\text { ntees }\end{array}$ & 7 & 0 & 2 & 0 \\
\hline $\begin{array}{l}\text { Real estate } \\
\text { investments }\end{array}$ & 1 & 3 & 1 & 2 \\
\hline Franchising & 2 & 0 & 2 & 1 \\
\hline $\begin{array}{l}\text { Competition } \\
\text { law }\end{array}$ & 0 & 2 & 0 & 3 \\
\hline Agencies & 0 & 1 & 0 & 2 \\
\hline Leases & 0 & 1 & 2 & 0 \\
\hline $\begin{array}{l}\text { Aboriginal } \\
\text { affairs }\end{array}$ & 0 & 1 & 1 & 1 \\
\hline Taxation & 0 & 0 & 3 & 0 \\
\hline Breach of trust & 1 & 0 & 0 & 1 \\
\hline $\begin{array}{l}\text { Administrative } \\
\text { law }\end{array}$ & 1 & 0 & 0 & 1 \\
\hline Human rights & 1 & 0 & 0 & 0 \\
\hline $\begin{array}{l}\text { Intellectual } \\
\text { property }\end{array}$ & 1 & 0 & 0 & 0 \\
\hline Restitution & 0 & 1 & 0 & 0 \\
\hline $\begin{array}{l}\text { Abuse of } \\
\text { process by } \\
\text { regulatory } \\
\text { agency }\end{array}$ & 0 & 1 & 0 & 0 \\
\hline Native title & 0 & 0 & 1 & 0 \\
\hline Admiralty & 0 & 0 & 1 & 0 \\
\hline $\begin{array}{l}\text { Misfeasance in } \\
\text { public office }\end{array}$ & 0 & 0 & 0 & 1 \\
\hline
\end{tabular}

As shown by the table above, from 4 December 2004 there was a significant increase in the number of proceedings being instituted with respect to the grievances of both shareholders and investors (with respect to advice provided by professional advisers). Shareholder class actions were, in fact, the most common types of class actions commenced in the final quarter of the study period.

Shareholder class actions are among the few types of class actions that regularly involved companies as class members, as they frequently involved not just retail investors, but also institutional investors. Thus the probability of companies acting as class representatives in these cases is higher than in other types of class actions. In fact, we discovered that almost half of the shareholder class actions initiated in the last quarter of the study period were led by a corporate class representative. ${ }^{25}$ Conversely, during this final quarter there was a sharp decrease in the kinds of Part IVA proceedings, such as product liability cases, where the victims of the impugned conduct (and thus the class representatives) comprised predominantly of individuals.

The proliferation of shareholder class actions in the final quarter of the study period also coincided with the emergence and subsequent legitimisation of commercial litigation funding, following the landmark decision of the High Court of Australia (Australia's highest court) in Campbells Cash and Carry Pty Ltd v Fostif Pty $L t d .^{26}$ This ruling confirmed the legality of litigation funding ${ }^{27}$ and thus

25 Only four institutional investors have acted as class representatives. With respect to US securities class actions, "[e]stimates as to how often institutions serve as lead plaintiff ranged from eight to twelve percent before 2005, to sixty-five percent in 2009": Burch, ibid.

26 (2006) 229 CLR 386. 
removed some of the disincentives that companies had previously faced when deciding to head a class action. Litigation funders can eliminate or reduce (depending on the terms of the funding agreement) the prospect that the class representative will be required to pay significant costs in the proceeding. ${ }^{28}$ It thus minimises the financial risk for companies undertaking the role of class representative. Over $73 \%$ of the Part IVA proceedings filed in the final quarter of the study period, which featured a corporate class representative, were funded by a litigation funder for at least part of the litigation. Thus, it appears that companies frequently utilised the benefits provided by litigation funders and, perhaps as a consequence, acted as class representatives more often in this quarter.

\section{Repeat Class Representatives}

A significant number of class representatives assumed that role on more than one occasion; that is, they were class representatives in multiple Part IVA proceedings. The table below divides them into several categories.

\section{Table 4: Repeat class representatives}

\begin{tabular}{|l|l|l|}
\hline Categories of class representatives & $\begin{array}{l}\text { Total number of repeat class } \\
\text { representatives }\end{array}$ \\
\hline Individuals & 32 & \\
\hline Companies & 2 \\
\hline Trade union & 1 \\
\hline ACCC & 1 \\
\hline
\end{tabular}

As evidenced by Table 4, there were a total of 36 class representatives who assumed this role on multiple occasions. A significant proportion of them (32) were individuals. References to "professional class representatives" may be found in the American literature. ${ }^{29}$ Coffee $\mathrm{Jr}$, for instance, has drawn attention to "wellknown individuals who possess broad (but thin) securities portfolios and have served as the lead plaintiff in numerous previous class actions". ${ }^{30}$ The 32 Australian repeat class representatives referred to above may not be regarded as

27 Ibid. The High Court held that the representative proceeding before the Court - which was funded by a commercial litigation funder that exercised a significant level of control over the way the litigation was conducted and was entitled to receive a significant percentage of the proceeds generated by the proceeding - did not constitute an abuse of process.

28 For details regarding the various forms of financial support provided by commercial litigation funders to class representatives in Part IVA proceedings during the study period, see Vince Morabito, Litigation Funders, Competing Class Actions, Opt Out Rates, Victorian Class Actions and Class Representatives (An Empirical Study of Australia's Class Action Regimes: Second Report, September 2010), at 38, online: Global Class Action Exchange <http://globalclassactions.stanford.edu/empirical> [Morabito, Second Report].

29 See e.g. Jean Wegman Burns, "Decorative Figureheads: Eliminating Class Representatives in Class Actions" (1990) 42 Hastings LJ 165 at 181.

30 John C Coffee Jr, "Understanding the Plaintiff's Attorney: The Implications of Economic Theory for Private Enforcement of Law through Class and Derivative Actions" (1986) 86 Colum L Rev 669 at 682. But see TE Willging, LL Hooper \& RJ Niemic, Empirical Study of Class Actions in Four Federal Districts: Final Report to the Advisory Committee on Civil Rules (Washington: Federal Judicial Center, 1996) at 25: "we found few multiple appearances of named plaintiffs in the four districts. Pooling all the names of class representatives into one file with 353 names of class representatives from 141 cases, we identified duplicate appearances by four individuals and one corporation". 
professional class representatives given that none of them acted as class representatives in class actions that were brought with respect to different and unrelated legal disputes. ${ }^{31}$ All of them were class representatives in multiple class actions brought with respect to essentially the same disputes. ${ }^{32}$

Somewhat more surprising, and thus more fascinating, is the fact that we identified 45 individuals who were class representatives in one or more Part IVA proceedings and class members in other Part IVA proceedings. ${ }^{33}$ In most circumstances, this scenario was attributable to the filing of class actions with respect to essentially the same disputes where there was total or partial overlap between the relevant groups of claimants. Some of these related class actions were filed by the same lawyers while others were competing class actions, as they were filed by different lawyers. But in migration ${ }^{34}$ and shareholder class actions, we found some instances of individuals being class representatives in class actions that were unrelated to other class actions in which these individuals were class members. Sometimes these class representatives were class members in the "other" class actions simply because they fell within the description of the relevant classes of claimants; whilst, on other occasions, the classes were limited to those claimants whose names appeared on lists attached to either the pleadings or the affidavits filed by class counsel and the names of these individuals appeared on these lists.

After removing repeat class representatives, we discovered that there were a total of 395 different persons and entities that acted as class representatives in the 250 Part IVA proceedings commenced during the study period. This is the data that will be employed in the remainder of the article.

Table 5: Categories of class representatives (excluding repeat class representatives)

\begin{tabular}{|l|l|}
\hline Categories of class representatives & Total \\
\hline Individuals & 339 \\
\hline Companies & 51 \\
\hline Trade unions & 2 \\
\hline ACCC & 1 \\
\hline Local government council & 1 \\
\hline Unincorporated association & 1 \\
\hline
\end{tabular}

31 For an example of a Canadian person acting, in multiple and unrelated class actions, as class representative in litigation run by the same law firm, see Singer v Schering-Plough Canada Inc [2010] OJ No 113 at para 12 (ONSC), Strathy J.

32 See e.g. Kirby v Centro Properties Ltd [2008] FCA 1505 where Mr Kirby brought, with the help of the same law firm, two virtually identical Part IVA proceedings against four companies in the Centro group. The only difference between the two class actions was that in one proceeding the defendants were two Centro companies whilst in the other class action the defendants were the remaining two Centro companies. See generally, Morabito, Second Report, supra note 28 at ch 2.

33 This data is not limited to contemporaneous class actions. Thus, it includes individuals who were class members in proceedings that were filed at a time when the class actions "headed" by these individuals had already come to an end and vice versa.

34 In 2000, Australia's Department of Immigration and Multicultural Affairs lamented that in some migration class actions a significant number of class "members were identified as moving between class actions": Department of Immigration and Multicultural Affairs, "Submission to the Joint Standing Committee on Migration on the Migration Legislation Amendment Bill (No 2) 2000" (Canberra: Parliament of Australia, 2000) at 10. 


\section{E. Motivations of non-corporate class representatives}

It is unambiguously clear that despite an increase in the number of corporate class representatives in the latter end of the study period, class representatives were far more likely to be individuals than any other entity. In many respects, accepting to be a class representative represents an irrational strategy, especially for individuals. ${ }^{36}$ As explained by Justice Wilcox of the Federal Court of Australia, three years after Part IVA came into operation:

The problem is that a representative party is exposed to the risk of an order to pay the costs of a respondent or respondents (the amount of which will usually be increased by the very fact that the proceeding is a representative one), without gaining any personal benefit from the representative role. So there is little or no incentive for a person to act as a representative party. Unless the person's potential costs are covered by someone else, there is a positive disincentive to taking that course.

The unenviable position of class representatives was described as follows in 2002 by the current Chief Justice for Ontario, Winkler CJO:

The common issue trial will determine the litigation for all class members. Nonetheless, the plaintiffs will be the only class members exposed to costs in the litigation, up to the conclusion of that trial. For that matter, they are the only members of the proposed class exposed to costs on this application for certification. Under virtually any other procedure, they would be exposed to less costs individually. Notwithstanding this, they stand to gain no more from the class proceeding than any other class member on a proportionate basis or than they would in individual lawsuits.

The significant publicity and controversy that have been generated by the involvement of commercial litigation funders in Part IVA proceedings over the last few years may prompt some to conclude that the picture painted above, with

35 See e.g. Mandeville v Manufacturers Life Insurance Co (2002) 40 CPC ( $\left.5^{\text {th }}\right) 182$ at para 62 (ONSC), Nordheimer J ("no sensible plaintiff, irrespective of the validity of his or her claim would choose to invest $\$ 2$ million in order to recover $\$ 15,000$ ").

See e.g. Dugal v Manulife Financial Corporation 2011 ONSC 1785 at para 28, Strathy J ("the grim reality is that no person in their right mind would accept the role of representative plaintiff if he or she were at risk of losing everything they own"). See also Attis v Canada (Minister of Health) [2010] OJ No 3760 at para 84 (ONSC), Cullity J [Attis].

37 Woodlands v Permanent Trustee Co Ltd (1995) 58 FCR 139 at 145. See also Michael P Abdelkerim, "Class Counsel's Ethical Obligations" (2004) 18 Windsor Rev Legal Soc Issues 105 at 110; Jocelyn Kellam, S Stuart Clark \& Christina Harris, "Representative Actions: a Review of 15 years of product liability class action litigation in Australia - Part I" (2008) 16 Trade Practices Law Journal 166 at 183; and Milfull v Terranora Lakes Country Club Ltd [2006] FCA 801 at para 6, Dowsett J.

381176560 Ontario Limited $v$ The Great Atlantic \& Pacific Company of Canada Limited (2002) 62 OR (3d) 535 at 553 (ONSC). See also Chopik v Mitsubishi Paper Mills Ltd [2003] OJ No 192 at para 17, Shaughnessy J; and Attis, supra note 36 at paras 6-7. 
respect to the costs exposure and financial burdens of class representatives, is inapplicable to Australia. It is submitted, however, that such a response is flawed for essentially two reasons. The first is that during the study period litigation funders provided financial support to class representatives in only 18 or $7.2 \%$ of the 250 Part IVA proceedings that were brought in this period. ${ }^{39}$ Equally significant is the fact that, due to the extremely strict criteria that litigation funders invariably apply to determine the legal proceedings that they support, ${ }^{40}$ there will always be a substantial number of unfunded class actions.

An obvious question is why so many individuals decided to become class representatives in Part IVA proceedings. ${ }^{41}$ The very limited data, contained in the court files $^{42}$ and in media reports on this issue, reveals a number of reasons for individuals assuming this role. ${ }^{43}$ Reasons include a sense of moral obligation to

39 Vince Morabito and Vicki Waye, "Reining in Litigation Entrepreneurs: A New Zealand Proposal" [2011] New Zealand Law Review 323 at 340. For rare instances of Canadian class actions supported by commercial litigation funders, see The Trustees of the Labourers' Pension Fund of Central and Eastern Canada v Sino-Forest Corp 2012 ONSC 2937; Fehr v Sun Life Assurance Company of Canada 2012 ONSC 2715; Smith v Sino-Forest Corp [2012] OJ No 88 at para 140 (ONSC), Perell J [Sino-Forest Corp]; Dugal v Manulife Financial Corporation 2011 ONSC 1785 and 2011 ONSC 3147; and Metzler Investment GMBH v Gildan Activewear Inc (2009) 81 CPC $\left(6^{\text {th }}\right) 384$, [2009] OJ No 3315. See also Fairview Donut Inc v The TDL Group Corp 2012 ONSC 152 at paras 360-363, Strathy J. For a comparative and excellent analysis of third party litigation funding, see Jasminka Kalajdzic, Peter Cashman \& Alana Longmoore, "Justice for Profit: A Comparative Analysis of Australian, Canadian and US Third Party Litigation Funding" (2013) 61 Am J Comp L No 2 online: Social Science Research Network <http://papers.ssrn.com/sol3/papers.cfm?-abstract_id $=2064980>$. In Canada, whenever class representatives have been provided with an indemnity against any adverse costs awards, it has usually come from class counsel. See e.g. Sino-Forest Corp ibid at paras 141, 246.

40 See e.g. John Walker, Susanna Khouri \& Wayne Attrill, "Funding Criteria for Class Actions" (2009) 32 UNSWLJ 1036.

41 In the US, semi-structured interviews of 20 class representatives in consumer protection class actions revealed that "most named plaintiffs in this study desired both individual and collective forms of justice, including monetary relief for themselves and the entire class, assurances that the defendant would cease its offending conduct, and some sense that justice had been done. But many named plaintiffs are looking for more: they hope, and frequently expect, that the class action to which they aligned themselves would demonstrate that the defendant was wrong and, by extension, change the behavior of actors throughout a particular industry": Stephen Meili, "Collective Justice or Personal Gain? An Empirical Analysis of Consumer Class Action Lawyers and Named Plaintiffs" (2011) 44 Akron L Rev 67 at 70.

42 Unlike Canadian class representatives, aspiring Australian class representatives need not establish to the Court's satisfaction that they will fairly and adequately represent the interests of class members before they are able to employ the class action procedure, subject to one exception. The exception is where one or more class members take the extreme step of seeking the replacement of the class representative on the basis of inadequate representation of the interests of class members: Part IVA, supra note 8 at s 33T. As a consequence, unlike their Canadian counterparts, Australian class representatives are not normally required: (a) to file affidavits, at the outset of the proceeding, dealing with their ability to represent the representative group and the reasons for assuming that role; and (b) to be cross-examined by their opponent's counsel regarding this issue. With respect to these requirements in Canada see White $v$ Glaxosmithkline Inc, 2010 SKQB 108 at para 11, Ball J [White] and Millgate Financial Corporation Limited v BF Realty Holdings Limited, [1997] OJ No 4020 at para 10 (ON Div Ct), Farley J ("those ... disagreeing with the representative plaintiff being ... representative of the class ... should be allowed a reasonable latitude or exploration to see whether there are any skeletons in the closet which may legitimately be advanced by them as showing unsuitability").

43 A Canadian scholar indicated in 1998 that "few class actions make economic sense to the individual plaintiff: however, class actions are still launched. Whether motivated by politics, 
head the class because they believed that a wrong had been committed and those responsible should be held accountable. ${ }^{44}$ On several occasions a class representative had already assumed a leadership position amongst the aggrieved persons prior to the litigation and thus it was a natural progression to head the class action.

These positions of leadership encompassed the running of a committee set up for the purpose of co-ordinating the litigation, being a shop steward for a trade union, or being the elected spokesperson for a group of asylum seekers. Others undertook the role because they had some background knowledge or expertise in the subject matter of the class action. Some class representatives claimed that they assumed the role because they believed that there were reasonable prospects of success while others undertook the role solely because no one else had agreed to become a class representative.

Unfortunately, we also identified a handful of instances of class representatives claiming: (a) that they never consented to being class representatives; ${ }^{45}$ or (b) that their consent was based on misleading, non-existent or grossly inadequate advice from the lawyers running the class action, regarding their potential costs exposure in the event of an unsuccessful outcome.

The reasons behind class representatives deciding to assume this important role are thus quite varied. We will now explore how diverse the class representatives themselves were by delving deeper and exploring many of the fundamental characteristics of these individuals. We will then determine how representative they are of Australia's population. But before doing so, we canvass the personal characteristics that Australia's top four plaintiff law firms look for in class representatives.

\section{F. What class counsel look for in class representatives}

As noted, in 2005, by Winkler J of the Ontario Superior Court of Justice (as he then was), "access to justice and the other laudable goals [of class action regimes]

principle, litigiousness, crankiness, or desire for fame or empowerment, individuals will come forward": David Crerar, "The Restitutionary Class Action" (1998) 56 UT Fac L Rev 47 at 92.

44 This was, for instance, the major reason that prompted the class representatives to assume this role in Australia's first successful cartel class action and the country's first successful shareholder class action: see, respectively, "Affidavit" (filed in Bray v F Hoffmann-La Roche Ltd; 28 July 2003 at para 17); and F Shiel, "Court Backs \$112m Payout to GIO Shareholders" The Age (27 August 2003) 5. With respect to similarly motivated class representatives in other Part IVA proceedings, see M Jacobs, "Farmers all class in AWB settlement"Australian Financial Review (16 February 2010) 3; T Bawden, "Jilted Investors Going for Broke", The Advertiser (28 February 2004) 75; and "Damages Vindicate a Fight to the Death", The Australian (13 April 2002) 4.

45 See e.g. Vince Morabito, "Clashing Classes Down Under - Evaluating Australia's Competing Class Actions through Empirical and Comparative Perspectives” (2012) 27 Conn J Int'1 L 245 at 302. In relation to two class actions brought in the Supreme Court of Victoria, there have been judicial findings of lack of consent on the part of the class representatives: see SPI supra note 5; and Cohen, supra note 5. With respect to Canadian class actions, see $R v$ Spurr [2009] SJ No 729 at para $13(\mathrm{QB})$, Laing CJ; and White, supra note 42 at para 11.

46 For instances of "uninformed or misinformed consent" by Canadian class representatives to the commencement of class action proceedings, see Poulin v Ford Motor Co of Canada [2007] OJ No 4988 at para 57 (ONSC), Mackenzie J. See also Attis, supra note 36; and Garry D Watson, "Class Actions: The Canadian Experience" (2001) 11 Duke J Comp \& Int'l L 269 at 275. 
will only be served as long as there are counsel willing to take risks in order to advance the cause of plaintiffs of modest means or modest claims". ${ }^{47}$

Thus, an analysis of the characteristics of class representatives would not be complete without a consideration of the characteristics that class counsel regard as desirable or essential on the part of class representatives. Accordingly, we contacted Maurice Blackburn, Slater \& Gordon, Shine Lawyers and Duncan Basheer Hannon and asked them what criteria they applied when faced with multiple claimants willing to act as class representatives.

These four law firms were involved in a total of $90(36 \%)$ of all the Part IVA proceedings filed during the study period. The responses provided by these firms may be divided in two general categories: those that placed emphasis on the individual claims of class representatives and those that focused on their personal characteristics. We are, of course, interested in the latter information.

All four firms drew attention to the need for the class representative to be able to proceed to the resolution of the litigation, including possible settlements and appeals. They also noted that in order to achieve this desirable objective, the class representatives need to be able to dedicate sufficient time ${ }^{49}$ and resources ${ }^{50}$ to the litigation. It also requires both psychological and physical wellbeing. In this context, attention was also drawn to the need for the class representative to be free of extraneous financial or physical concerns.

They also placed emphasis on the need for class representatives to be good witnesses. Two firms noted that this required the class representative to be balanced and honest. ${ }^{51}$ Another firm opined that in order to be a good witness one must not be inclined to exaggerate or overstate the issues. This information will be useful in understanding and assessing the empirical data that will be presented in the remainder of the article.

\section{THE GENDER OF CLASS REPRESENTATIVES}

We identified the sex of all natural persons who acted as class representatives in Part IVA proceedings commenced in the study period except for one.

47 Caputo v Imperial Tobacco Ltd (2005) 74 OR (3d) 728 at para 42 (ONSC). But, of course, as explained by the Saskatchewan Court of Appeal in 2007, "while the court is not unaware of the practical realities of class action litigation, the fundamental fact is that, of necessity, claims are brought by plaintiffs and in the name of plaintiffs. They are not brought by lawyers or in the name of lawyers": Englund v Pfizer Canada Inc [2007] SJ No 273 at para 50 (Sask CA).

48 In the US, semi-structured interviews of 33 lawyers who acted for class representatives in consumer protection class actions revealed that "lawyers usually want named plaintiffs with an array of goals, particularly collective justice goals, as well as a sense of anger or injustice directed towards the defendant. Such motivations render these named plaintiffs more likely to endure the lengthy litigation process and the temptation to accept early settlement offers that would provide them with individual compensation but leave the rest of the class without a recovery and their lawyer with only a modest fee": Meili, supra note 41 at 102.

49 As one law firm explained, attention is placed by their solicitors on the ability of class representatives "to provide timely instructions, comply with court deadlines, attend mediation and provide evidence at trial”: Interviews with Australian plaintiff law firms (January 2012) (transcripts on file with authors).

50 As noted by one law firm, "[we] look for someone of substance". Ibid.

51 Supra note 49.

52 We were unable to determine the gender of the class representative in question because only the surname of this person was provided in the pleadings and the proceeding did not last long enough 
Table 6: Gender of class representatives

\begin{tabular}{|l|l|l|l|}
\hline Male & Female \\
\hline Total number & $\begin{array}{l}\text { \% of all } \\
\text { individual class } \\
\text { representatives }\end{array}$ & Total number & $\begin{array}{l}\text { \% of all } \\
\text { individual class representatives }\end{array}$ \\
\hline 220 & $64.90 \%$ & 118 & $34.81 \%$ \\
\hline
\end{tabular}

Table 7: Persons in Australia ${ }^{53}$ by sex $^{54}$

\begin{tabular}{|l|l|l|l|l|}
\hline & Male & Female & \multicolumn{2}{|c|}{$\begin{array}{l}\text { of total } \\
\text { population }\end{array}$} \\
\hline Year & Total number & $\begin{array}{l}\text { \% of total } \\
\text { population }\end{array}$ & Total number & $50.4 \%$ \\
\hline 1991 & $8,362,660$ & $49.6 \%$ & $8,487,674$ & $50.5 \%$ \\
\hline 1996 & $8,849,224$ & $49.5 \%$ & $9,043,199$ & $50.6 \%$ \\
\hline 2001 & $9,365,941$ & $49.4 \%$ & $9,606,409$ & $50.7 \%$ \\
\hline 2006 & $9,896,503$ & $49.3 \%$ & $10,165,148$ & \\
\hline
\end{tabular}

It is evident when comparing the two tables above that there is a clear disparity between, on the one hand, the male to female ratio of class representatives in Part IVA actions and, on the other hand, the same ratio with respect to the general Australian population, as ascertained by the Australian Bureau of Statistics [ABS] from the data collected from the 1991, 1996, 2001 and 2006 censuses. There were significantly more males who were class representatives than females. In fact, there were almost twice as many. Conversely, it is evident from ABS data obtained during the census years that there were actually slightly more females living in Australia than there were males.

The reasons for the higher prevalence of male class representatives in Part IVA actions are not immediately apparent. There are no inherent qualities required of a class representative which are more applicable to a particular sex. However, embedded societal trends may contribute to this patent disproportionality. It is widely acknowledged that there has been, and still is, gender inequality in Australia. ${ }^{55}$ It is evident that men tend to hold the significant majority of leadership positions across all sectors, even in many female dominated industries. ${ }^{56}$ For example, the Equal Opportunity for Women in the Workplace Agency has found that women have been, and remain, under-represented in key leadership positions in the Australian Securities Exchange's [ASX] top 200 corporations. ${ }^{57}$ In 2002

to result in the production of documents that would reveal the personal details of this class representative.

53 This data includes overseas visitors.

54 Australian Bureau of Statistics, 2001 Census Community Profile Series: Time Series Profile, Table 01: Selected Characteristics (Cat. No. 2003.0, 2003) and Australian Bureau of Statistics, 2006 Census Community Profile Series: Time Series Profile, Table 01: Selected Person Characteristics for Time Series (Cat. No. 2003.0, 2007) [Selected Person Characteristics].

55 Human Rights and Equal Opportunity Commission, 2008 Gender equality: What matters to Australian women and men (2008) at 3 online: Human Rights and Equal Opportunity Commission < http://www.hreoc.gov.au/sex_discrimination/listeningtour/ListeningTourCommunityReport.pdf $>$.

$56 \quad$ Ibid at 7.

57 Equal Opportunity for Women in the Workplace Agency, Pay, Power and Position; Beyond the 2008 EOWA Australian Census of Women in Leadership (2009) at 6, online: Equal Opportunity for Women in the Workplace Agency at <http://www.eowa.gov.au/Australian_Wo- 
only two chief executive officers of the top 200 ASX companies were female. Women also occupied only $8.2 \%$ of the board directorships and $8.4 \%$ of the executive manager positions in these companies. ${ }^{59}$ The corresponding findings in subsequent years were not dissimilar. The ABS has also reported that in 2008 only $29.6 \%$ of federal parliamentarians were women ${ }^{60}$ and only $36.7 \%$ of senior executive service managers in the Australian public service were female. ${ }^{61}$

It appears that these traditional societal trends have permeated into the realm of class actions. As adverted to above, the role of class representative is one that formally entails a significant degree of power as well as responsibility. ${ }^{62}$ Indeed, as explained by a Canadian court:

The representative plaintiff has a responsibility to prosecute the lawsuit, once certified, in the interests of the members of the class. Their duty is akin to that of a fiduciary. They must have adequate knowledge and ability to instruct counsel and they must act in the interests of the members of the class. They are answerable to the court for adequate performance of these obligations. $^{63}$

Therefore, it can be equated with a leadership role. ${ }^{64}$ The fact that there have been many more male class representatives than female class representatives may simply reflect traditional and current societal norms.

men_In_Leadership_Census/2008_Australian_Women_In_Leadership_Census/Pay_Power_Position/Pay_Power_Position_Beyond_the_Census.pdf $>$.

58 Equal Opportunity for Women in the Workplace Agency, 2002 Australian Census of Women Board Directors (2002) at 7, online: Equal Opportunity for Women in the Workplace Agency $<$ http://www.eowa.gov.au/Australian_Women_In_Leadership_Census/2002_Australian_Women_ In_Leadership_Census/2002_Census_Board_Directors.pdf> [2002 Australian Census].

592002 Australian Census, ibid.

60 Australian Bureau of Statistics, Gender Indicators, Australia, Jan 2012, Table: Federal Parliamentarians (Cat. No. 4125.0, 2012), online: ABS <http://www.abs.gov.au/ausstats/abs@.nsf/Lookup/by\%20-

Subject/4125.0 Jan\%202012 Main\%20Features Parliamentarians $\sim 6120>$.

61 Australian Bureau of Statistics, Gender Indicators, Australia, Jan 2012, Table: Senior Executive Service Managers (SES) in the Australian Public Service (APS) (Cat. No. 4125.0, 2012), online: ABS

<http://www.abs.gov.au/ausstats/abs@.nsf/Lookup/by\%20Subject/4125.0 Jan\%202012 Main\%2 0Features $\sim$ Australian\%20Public\%20Service\%20senior\%20and\%20middle\%20managers 6140>.

62 See e.g. Duzan v Glaxosmithkline Inc, 2011 SKQB 118 at para 41, Ball J (referring to "the requirement for a genuine representative plaintiff with a mandate to act in the best interests of the class as a whole by participating in the direction of litigation, instruction of class counsel ..."). See also Englund, supra note 47 at para 51; and Fantl v Transamerica supra note 3 at para 63.

63 Hoffman $v$ Monsanto Canada Inc [2005] 7 WWR 665 at para 337 (Sask QB). See also SPI, supra note 5 at para 119; Bray v F Hoffman-La Roche Ltd [2003] FCA 1505 at para 15 (Merkel J); Monsanto Canada Inc v Hoffman [2002] SJ No 607 at para 16 (Sask CA) Tallis, Gerwing and Sherstobitoff JJA; Schroeder v DJO Canada Inc [2010] SJ No 220 at paras 150-151 (Sask QB), Popescul J; Lau v Bayview Landmark Inc (2004) 50 CPC ( $\left.5^{\text {th }}\right) 113$ at para 19 (ONSC), Cullity J; Brooks v Canadian Pacific Railway Ltd [2007] SJ No 367 at para 192 (Sask QB), Dawson J; and Lambert, supra note 5 at paras 136-138.

64 British Columbia's Court of Appeal has recently explained that the intangible costs borne by class representatives include "the sometimes not inconsiderable weight of being the leader of the 
It may also be the case that women are not often selected by solicitors to act as class representatives, although the attributes that Australia's top plaintiff firms look for in class representatives (outlined in Part IIF above) are gender neutral. One of the reviewers of this article queried whether this gender imbalance may be attributed to the solicitors running class actions being mostly male. This comment prompted us to go back to the court files to ascertain the gender of the most senior solicitors who acted for the class representatives in Part IVA proceedings where at least one of the class representatives was a natural person. We then collected data to determine whether, when the most senior plaintiff solicitor(s) included a least one woman, there was a greater proportion of female class representatives. We found that in $73.66 \%$ of the class actions that featured at least one natural person acting as class representative, the most senior solicitor(s) running the litigation did not include any female solicitors. With respect to these cases, the percentage of male class representatives was $66.67 \%$ and thus the percentage of female class representatives was $33.33 \%$. With respect to the $26.34 \%$ of the class actions - that featured at least one natural person acting as class representative and at least one female solicitor among the most senior solicitor(s) running the proceeding - the male class representatives were $61.19 \%$ and thus the female class representatives constituted $38.81 \%$ of all the non-corporate class representatives.

It may simply be that women themselves are reluctant to take on the role. Women may be reluctant to undertake the role due to its possible incompatibility with familial responsibilities. ${ }^{65}$ It is evident that women are more likely to be the primary caregivers of children. The ABS has found that female parents spent more than twice as much time, each day caring for children aged 0-14 years, than did male parents in both 1997 and 2006. ${ }^{66}$ It was also reported by the ABS that in 1997 and 2006 women spent more hours on work (employment related and unpaid) than males. ${ }^{67}$ The role of class representative may thus often be incompatible with a woman's familial and work responsibilities due to the time commitment frequently required for that role. ${ }^{68}$ This may have contributed to the lower number of women accepting the role.

claimants": Parsons v Coast Capital Savings Credit Union [2010] BCJ No 1184 at para 20 [Parsons].

65 See e.g. A Lampe, "Under Pressure" Sydney Morning Herald (24 September 2003) 7 where it was reported that the class representative in a Part IVA proceeding was "glad she took the action, the outcome of which is still to be determined. But she also said that she had no idea what a traumatic ordeal she was in for".

66 Australian Bureau of Statistics, Gender Indicators, Australia, Jan 2012, Ch: Work and Family Balance: Caring for Children (Cat. No. 4125.0; 2012) online: ABS <http://www.abs.gov.au/ausstats/abs@.nsf/Lookup/by+Subject/4125.0 Jan+2012 Main+Features Caring+for+children 412 $0>$.

67 Australian Bureau of Statistics, Gender Indicators, Australia, Jan 2012, Table: Total Number Of Hours And Minutes Per Day Spent On Work (Employment Related And Unpaid) (a)(b)(c), 15 years and over (Cat. No. 4125.0, 2012), online: ABS

<http://www.abs.gov.au/ausstats/abs@.nsf/Lookup/by\%20-

Subject/4125.0 Jan\%202012 Main\%20Features Engagement\%20in\%20work\%20(employment $\% 20$ related\%20and\%20unpaid) 4110>.

68 It will be recalled that the ability of class representatives to devote sufficient time to the litigation was regarded as an important consideration by the country's leading four plaintiff law firms. See also James D Cox, Randall S Thomas \& Dana Kiku, "Does the Plaintiff Matter? An Empirical Analysis of Lead Plaintiffs in Securities Class Actions" (2006) 106 Colum L Rev 1587 at 1606. 
An analysis of the types of substantive claims that have been advanced in class actions also provides useful data as to why women are under-represented among class representatives. In many Part IVA proceedings, the substantive claims that were advanced on behalf of the class were not gender specific. The class comprised both male and female claimants and the proportions of males and females undertaking the role of class representatives were, more often than not, fairly even. However, there were some types of class actions which saw significantly more male than female class representatives. ${ }^{69}$ For example, as shown in the table below, in shareholder class actions, migration class actions and industrial class actions, $81 \%, 77 \%$ and $68 \%$ of the class representatives were men, respectively.

Table 8: Gender of class representatives divided by type of substantive claim

\begin{tabular}{|c|c|c|}
\hline Type of Claim & $\%$ of Males & $\%$ of Females \\
\hline Loans/guarantees & $62.50 \%$ & $37.50 \%$ \\
\hline Migration & $77.50 \%$ & $22.50 \%$ \\
\hline $\begin{array}{l}\text { Product liability (defective goods and services; mass } \\
\text { torts) }\end{array}$ & $58.23 \%$ & $41.77 \%$ \\
\hline Consumer protection & $61.11 \%$ & $38.89 \%$ \\
\hline Shareholder actions & $81.25 \%$ & $18.75 \%$ \\
\hline Human rights & $100.00 \%$ & $0 \%$ \\
\hline Breach of trust & $50.00 \%$ & $50.00 \%$ \\
\hline Administrative law & $66.67 \%$ & $33.33 \%$ \\
\hline Real estate investments & $72.73 \%$ & $27.27 \%$ \\
\hline Franchising & $60.00 \%$ & $40.00 \%$ \\
\hline Industrial & $68.42 \%$ & $31.58 \%$ \\
\hline Intellectual property & $100 \%$ & $0 \%$ \\
\hline Investment advice (professional advisers) & $53.85 \%$ & $46.15 \%$ \\
\hline Competition law & $0 \%$ & $100 \%$ \\
\hline Restitution & $66.67 \%$ & $33.33 \%$ \\
\hline Agencies & $100 \%$ & $0 \%$ \\
\hline Abuse of process by regulatory agency & $0 \%$ & $0 \%$ \\
\hline Leases & $42.86 \%$ & $57.14 \%$ \\
\hline Aboriginal affairs & $66.67 \%$ & $33.33 \%$ \\
\hline Investment schemes & $56.00 \%$ & $44.00 \%$ \\
\hline Native title & $100.00 \%$ & $0 \%$ \\
\hline Taxation & $100.00 \%$ & $0 \%$ \\
\hline Admiralty & $0 \%$ & $0 \%$ \\
\hline Misfeasance in public office & $0 \%$ & $0 \%$ \\
\hline
\end{tabular}

A recent study of ownership of shares in Australia has revealed that in $200840 \%$ of adult Australian men were direct share owners whilst in 2010 this proportion increased to $45 \%$. The same study showed that $34 \%$ and $30 \%$ of adult Australian women were direct share owners in 2010 and 2008, respectively. ${ }^{70}$ This data

69 Conversely, there were four product liability cases where all the class members were women and thus there could only be female class representatives. Three of these cases related to allegedly faulty breast implants whilst the remaining class action related to allegedly defective sterilisation devices. See, respectively, Bates v Dow Corning (Australia) Pty Limited [2005] FCA 927; and Bright v Femcare Ltd (2002) 195 ALR 574.

70 See Australian Securities Exchange, 2010 Australian Ownership Study, online: ASE <http://www.as-X.com.au/documents/resources/2010_australian_share_ownership_study.pdf >. A greater proportion of male shareholders was also revealed by a similar study that was conducted 
provides a likely explanation for the greater male participation in the leadership of representative groups in shareholder class actions but it does not appear to justify, on its own, the fact that there are four male class representatives for every female class representative in shareholder class actions.

A contributor to the higher number of male class representatives in migration class actions may probably be found in the barriers women have faced when accessing the humanitarian and refugee visa system. The Guidelines on Gender Issues for Decision-Makers, produced by the Department of Immigration and Multicultural Affairs in 1996, recognised that there may be social and cultural barriers faced by women lodging humanitarian visas. ${ }^{71}$ It claimed, for example, that "in families where the male head of the household seeks asylum, claims relating to the female members of the family unit may not be mentioned, may be ignored or may not be given any weight by either the male head of the household or the decision makers, or the female applicant herself". ${ }^{72}$ There is a tendency for protection or humanitarian visa applications to be made by the male head of the household. ${ }^{73}$ It is therefore likely that these barriers women have faced, when lodging visa applications, have contributed to a limited number of women being involved in migration class actions and subsequently a limited number of women acting as class representatives in these types of class actions.

The higher number of male class representatives in industrial class actions may be attributed, to some extent, to the fact that there were more occupations the subject of class actions which were dominated by men, compared to occupations dominated by women. More than a third of industrial Part IVA proceedings involved occupations or industries which may be regarded as being dominated traditionally by men. ${ }^{74}$ They included the following occupations: mineworkers, pilots, bus drivers, truck drivers, stevedores, printers and police officers. Many of the remaining occupations, which featured in industrial class actions, may be regarded as gender neutral.

\section{THE AGE OF CLASS REPRESENTATIVES}

The age of 120 class representatives was identified. That is, we identified the age of over $35 \%$ of all the natural persons who acted as class representatives. The 120 class representatives came from a total of 89 cases. This represents $41.20 \%$ of

in 2002: see Australian Stock Exchange, 2002 Australian Share Ownership Study, online: ASE <http://www.asx.com.au/docu-ments/resources/ASXShareStudy2002.pdf >.

Department of Immigration and Multicultural Affairs, Refugee and Humanitarian Visa

Applicants: Guidelines on Gender Issues for Decision-Makers, (1996) 6, online: Center for Gender \& Refugee Studies

<http://cgrs.uchastings.edu/documents/legal/guidelines_aust.pdf $>$.

Ibid.

Ibid.

74 One of the reviewers of this article queried whether the selection of these workplace disputes, involving predominantly male workers, for class action litigation might be attributable to the leaders of the relevant unions that supported the litigation being male. Unfortunately, we do not have any comprehensive data on the gender of union leaders. For an empirical analysis of the major role that trade unions have played in Part IVA proceedings filed during the study period, see Jane Caruana and Vince Morabito, "Australian Unions - the Unknown Class Action Protagonists" (2011) 30 CJQ 473. 
the total number of class actions (216) where at least one natural person was among the class representatives.

\section{Table 9: Age of class representatives}

\begin{tabular}{|l|l|l|}
\hline Age group & $\begin{array}{l}\text { Total number of class } \\
\text { representatives }\end{array}$ & \% of class representatives \\
\hline $0-4$ years & 0 & $0 \%$ \\
\hline $5-14$ years & 2 & $1.66 \%$ \\
\hline 15-24 years & 3 & $2.50 \%$ \\
\hline $25-34$ years & 23 & $19.16 \%$ \\
\hline 35-44 years & 31 & $25.83 \%$ \\
\hline 45-54 years & 25 & $20.83 \%$ \\
\hline 55-64 years & 15 & $12.50 \%$ \\
\hline 65 years and over & 21 & $17.50 \%$ \\
\hline
\end{tabular}

Table 10: Australia's population by age $^{76}$

\begin{tabular}{|l|l|l|l|}
\hline Age group & $\begin{array}{l}\text { \% of total persons } \\
\mathbf{( 1 9 9 6} \text { census) }\end{array}$ & $\begin{array}{l}\text { \% of total persons } \\
\mathbf{2 0 0 1} \\
\text { census })\end{array}$ & $\begin{array}{l}\text { \% of total persons } \\
\mathbf{2 0 0 6} \\
\text { census })\end{array}$ \\
\hline 0-4 years & $7.1 \%$ & $6.6 \%$ & $6.3 \%$ \\
\hline 5-14 years & $14.5 \%$ & $14.2 \%$ & $13.4 \%$ \\
\hline 15-24 years & $14.5 \%$ & $13.7 \%$ & $13.8 \%$ \\
\hline 25-34 years & $15.5 \%$ & $14.6 \%$ & $13.5 \%$ \\
\hline 35-44 years & $15.3 \%$ & $15.2 \%$ & $14.8 \%$ \\
\hline 45-54 years & $12.6 \%$ & $13.7 \%$ & $13.9 \%$ \\
\hline 55-64 years & $8.4 \%$ & $9.4 \%$ & $11.0 \%$ \\
\hline 65 years and over & $12.1 \%$ & $12.6 \%$ & $13.3 \%$ \\
\hline
\end{tabular}

The class representatives in Part IVA proceedings conducted in the study period were aged between 7 years and 88 years. As can be seen from Table 9, the most common age group of class representatives was 35-44 years $(25.83 \%)$. This figure is significantly higher than the percentage (approximately 15\%) of persons in this age group in Australia during the "census" period from 1996 to 2006. It is also evident from the data contained in Table 10 that the percentages of people in each age group are more evenly spread, compared to Table 9, which contains a significant disparity between the percentages of class representatives aged 24 years and under and those aged 25 years and over.

Class representatives aged 24 years and under accounted for only $4.2 \%$ of all class representatives whose age we were able to determine. There were three minors who undertook this role with the assistance of a "next friend" and only two other class representatives were aged between 18 and 24 years. One factor which may have contributed to this obvious under-representation of younger people, among class representatives, is the nature of the role itself. As noted above, there is a significant degree of responsibility involved in representing potentially numerous class members. Solicitors may have been reluctant to appoint younger persons perhaps because they feel that they did not possess the required maturity to undertake this role and/or because of a determination that they would not make

75 This refers to the percentages of all class representatives whose age was ascertained.

76 Selected Person Characteristics, supra note 54. 
good witnesses. Younger people themselves may have been reluctant to assume the financial risks of an unfunded proceeding due the dire financial repercussions, for the class representative, in the event of an unsuccessful outcome.

Most interesting, however, when comparing Tables 9 and 10 above, is the number of class representatives aged 65 years and over. The percentage of class representatives aged 65 and over is above the total percentage of persons in this age group residing in Australia. We identified 21 class representatives who were aged 65 and over, which accounts for over $17 \%$ of all class representatives whose ages were ascertained. People in this age bracket accounted for approximately 12\% of all persons in Australia during the period from 1996 to 2006.

It appears reasonable to expect that when persons reach the age of 65 years they frequently desire a "winding down" of their life, including the amount of work and responsibility they undertake. This appears to be incompatible with being a class representative. However, the fact that individuals are likely to have dramatically reduced their number of paid working hours at this time of their life will render them extremely suitable for the role of class representative, as it will enable them to devote sufficient time to the litigation; a consideration that, as already noted, is of great importance to plaintiff lawyers. Therefore, it comes as no great surprise that at least thirty-one persons had retired from paid employment at the time that they became class representatives in Part IVA proceedings.

The significant number of older class representatives is also partly attributable to the nature of some of the claims that were advanced in Part IVA proceedings. For example, there were a combined total of 15 elderly class representatives in two Part IVA proceedings involving claims predominantly relevant to retirees. These cases concerned investments in a retirement village ${ }^{78}$ and an equity release scheme. ${ }^{79}$

This preference for class representatives at the older end of the age spectrum is reflected in the average and median age of class representatives. The average age of class representatives was almost 47 years and the median age of class representatives was 45 years, which is noticeably higher than the median age of persons in Australia during the study period. In 2006 the median age of persons in Australia was 37 years. $^{80}$ In 2001 the median age of persons in Australia was 35 years and in 1996 it was even lower (34 years). ${ }^{81}$ It is thus safe to conclude that when it comes to class representatives, age and experience have been favoured over youth.

77 From July 2006 - June 2007, 570,400 (72\%) people aged 65-69 years and 1,541,400 (86\%) people aged 70 years and over had retired from the labour force; Australian Bureau of Statistics, Retirement and Retirement Intentions, Australia, July 2006 to June 2007, Table 1.1; Persons aged 45 years and over, Retirement and retirement intentions - By labour force status, data cube: Excel spreadsheet (Cat. No. 6238.0, 2008). See Murphy v Overton Investments Pty Ltd [1999] FCA 1123.

79 See Haslam v Money for Living (Aust) Pty Ltd (Administrators Appointed) (ACN 107611 218) [2007] FCA 897.

80 Australian Bureau of Statistics, 2006 Census Community Profile Series: Time Series Profile, Table 02: Selected Averages and Medians for Time Series (Cat. No. 2003.0, 2007).

8 Ibid. 


\section{THE RESIDENCE OF CLASS REPRESENTATIVES}

The residence of over $88 \%$ of all the natural persons, who acted as class representatives, was identified. This data is presented in Table 11 whilst Table 12 divides Australia's population into the country's six states (New South Wales, Victoria, Queensland, South Australia, Western Australia and Tasmania) and two territories (Northern Territory and Australian Capital Territory). Table 13 reveals the registries of the Federal Court where Part IVA proceedings were filed.

\section{Table 11: Residence of class representatives}

\begin{tabular}{|l|l|l|}
\hline Place of residence & $\begin{array}{l}\text { Total no. of class } \\
\text { representatives }\end{array}$ & \% of class representatives \\
\hline New South Wales & 108 & $36.00 \%$ \\
\hline Victoria & 97 & $32.33 \%$ \\
\hline Queensland & 38 & $12.67 \%$ \\
\hline South Australia & 21 & $7.00 \%$ \\
\hline Western Australia & 17 & $5.67 \%$ \\
\hline Australian Capital Territory & 9 & $3.00 \%$ \\
\hline New Zealand & 3 & $1.00 \%$ \\
\hline Tasmania & 3 & $1.00 \%$ \\
\hline Northern Territory & 2 & $0.67 \%$ \\
\hline United Kingdom & 1 & $0.33 \%$ \\
\hline Nauru & 1 & $0.33 \%$ \\
\hline
\end{tabular}

Table 12: Australia's population by states and territories ${ }^{83}$

\begin{tabular}{|l|l|l|l|l|l|l|l|l|l|}
\hline & NSW & Vic. & QId & SA & WA & Tas. & NT & ACT & AUS \\
\hline $\mathbf{1 9 9 2}$ & $5,985,078$ & $4,465,415$ & $3,067,320$ & $1,458,800$ & $1,667,743$ & 471,023 & 169,713 & 296,192 & $17,581,284$ \\
\hline & $34.04 \%$ & $25.40 \%$ & $17.45 \%$ & $8.30 \%$ & $9.49 \%$ & $2.68 \%$ & $0.97 \%$ & $1.68 \%$ & \\
\hline $\mathbf{2 0 0 0}$ & $6,527,379$ & $4,770,042$ & $3,592,443$ & $1,508,028$ & $1,887,658$ & 471,416 & 196,257 & 316,816 & $19,272,644$ \\
\hline & $33.87 \%$ & $24.75 \%$ & $18.64 \%$ & $7.82 \%$ & $9.79 \%$ & $2.45 \%$ & $1.02 \%$ & $1.64 \%$ & \\
\hline $\mathbf{2 0 0 7}$ & $6,926,990$ & $5,246,079$ & $4,228,290$ & $1,591,930$ & $2,130,797$ & 495,772 & 217,559 & 340,818 & $21,180,632$ \\
\hline & $32.70 \%$ & $24.77 \%$ & $19.96 \%$ & $7.52 \%$ & $10.06 \%$ & $2.34 \%$ & $1.03 \%$ & $1.61 \%$ & \\
\hline
\end{tabular}

82 This refers to the percentages of all class representatives whose residence we were able to determine.

83 Australian Bureau of Statistics, Australian Historical Population Statistics, 2008, Table 1.1:

Population by sex, states and territories, 31 December, 1788 onwards (Cat. No. 3105.0.65.001: 2008) online: ABS <http://www.ausstats.abs.gov.au/Ausstats/subscriber.nsf/0/ED3777A70ACA4E0DCA25749B00176970/\$File/3105065001ds0001_2008.xls>. 
Table 13 - Part IVA proceedings filed in each registry of the Federal Court

\begin{tabular}{|l|l|}
\hline Registry of the Federal Court & $\begin{array}{l}\text { Number of Part IVA proceedings filed in } \\
\text { each registry }\end{array}$ \\
\hline New South Wales & $115(46 \%)$ \\
\hline Victoria & $89(35.6 \%)$ \\
\hline Queensland & $22(8.8 \%)$ \\
\hline Western Australia & $8(3.2 \%)$ \\
\hline South Australia & $8(3.2 \%)$ \\
\hline Australian Capital Territory & $4(1.6 \%)$ \\
\hline Northern Territory & $3(1.2 \%)$ \\
\hline Tasmania & $1(0.4 \%)$ \\
\hline
\end{tabular}

As is clear from Table 11, the highest number of class representatives resided in New South Wales, which accounted for $36 \%$ of the class representatives whose residence was ascertained. This figure closely correlates with the data (contained in Table 12) regarding the overall population of New South Wales. Approximately $34 \%$ and $33 \%$ of Australian residents resided in the state of New South Wales in 1992 and in 2007, respectively. New South Wales was also the Australian state in which most Part IVA proceedings were filed, with 115 (46\%) cases; so it is not surprising that many class representatives resided there. However, there is no legal requirement that a class representative must reside in the same state in which their proceeding was filed, and thus there is no guarantee that a class representative's state of residence and the state where the class action is filed will necessarily correlate. The topic of non-resident class representatives is discussed further in the next sub-section.

When comparing the three tables above, it also becomes plain that Victorian residents are over-represented among class representatives when compared with the national data. Victorian residents accounted for more than $32 \%$ of the class representatives in Part IVA actions, whereas in Australia, Victorians constitute around $25 \%$ of the population. Like New South Wales, this could also be at least partly attributable to the high percentage of class actions filed in that state even though, as already noted, the filing of a case in one state does not guarantee that the class representative will also reside there. There were 89 (35.6\%) Part IVA proceedings filed in Victoria during the study period. Conversely, Queensland residents appear to be under-represented among class representatives, with that state providing $12.67 \%$ of class representatives, whilst around $19 \%$ of the Australian population resides in Queensland. Even more fascinating is the fact that, as discussed below, many of these Queensland class representatives were involved in proceedings which were not filed in Queensland.

\section{A. Non-Resident Class Representatives}

Non-resident class representatives refer to those individuals who were class representatives in Part IVA actions that were brought in a different jurisdiction from where these individuals resided, at the time they became class representatives. We identified non-resident class representatives in $29.29 \%$ of the 
class actions in which the residence of the class representatives was identified. ${ }^{84}$ There were 79 non-resident class representatives: this represents $26.33 \%$ of all the class representatives whose residence we ascertained.

\section{Table 14: Non-resident class representatives}

\begin{tabular}{|l|l|l|}
\hline Place of residence & $\begin{array}{l}\text { Number of non-resident } \\
\text { class representatives }\end{array}$ & $\begin{array}{l}\text { \% of non-resident class } \\
\text { representatives }\end{array}$ \\
\hline Queensland & 18 & $22.78 \%$ \\
\hline New South Wales & 17 & $21.52 \%$ \\
\hline Victoria & 12 & $15.19 \%$ \\
\hline Western Australia & 10 & $12.66 \%$ \\
\hline South Australia & 8 & $10.13 \%$ \\
\hline Australian Capital Territory & 6 & $7.59 \%$ \\
\hline New Zealand & 3 & $3.80 \%$ \\
\hline Tasmania & 2 & $2.53 \%$ \\
\hline Northern Territory & 1 & $1.27 \%$ \\
\hline United Kingdom & 1 & $1.27 \%$ \\
\hline Nauru & 1 & $1.27 \%$ \\
\hline
\end{tabular}

It is evident from the table above that Queensland has provided the greatest number of non-resident class representatives. The reasons behind this finding are not easy to determine. There are no obvious factors which make Queensland stand out from the rest of the states when it comes to class representatives. What is clear is that most of the claims brought by class representatives residing in Queensland were quite widespread in their reach, often involving people from many areas of Australia, rather than pertaining to a specific, local area. It was also evident that in several of the proceedings, which involved non-resident class representatives from Queensland, there were multiple class representatives whilst in others there were multiple proceedings with respect to the same dispute. In many of these class actions there were also class representatives who did reside in the state in which the case was filed. Therefore, there were class representatives living in multiple states which emphasised the wide reach and "national" nature of the litigation.

Whatever the reasons behind these findings, it is unambiguously clear, from Table 14, that the area of residence of a person is evidently no hindrance to becoming a class representative in a class action. ${ }^{85}$ As already noted, over one quarter of the class representatives whose residence we could determine did not reside in the state in which their proceeding was filed.

84 If this percentage of non-resident class representatives had emerged from a study of Canada's class action regimes, the widespread phenomenon of the filing of "national class actions" in provincial courts would have, no doubt, been "blamed" for this state of affairs. In fact, in such actions, the appointment of non-resident class representatives frequently represents an important tool to ensure the adequate representation of the interests of those class members that do not reside in the province where the proceeding was filed: see generally Sino-Forest Corp, supra note 39 at para 222 and the references cited therein; and Dominguez v Northland Properties Corp (cob Denny's Restaurants) [2012] BCJ No 443 at paras 70-85, Fitzpatrick J. This strategy is not relevant to Part IVA proceedings given that they are filed in the country's national court to advance claims grounded on federal/national legislation and laws.

85 It is interesting to note that in 2005 Justice Hollingworth of the Supreme Court of Victoria remarked that "it may be fortuitous in a particular group proceeding that the lead plaintiff or plaintiffs happen to live in one State rather than another": Hall v Australian Finance Direct Limited [2005] VSC 306 at para 77. 
The involvement of class representatives, who resided outside Australia, also warrants some discussion. There were overseas-based class representatives in four Part IVA proceedings. In two related class actions, the same 3 individuals (all from New Zealand) were the sole class representatives. The court rejected an application for security for costs filed against them and the two proceedings were eventually settled. ${ }^{86}$ Before the settlement, this litigation resulted in the first and, to date, only judgment of the High Court of Australia on the construction of Part IVA. ${ }^{87}$ In another Part IVA proceeding, the sole class representative, who was working in London, stepped down as class representative and was replaced by an Australian resident when the defendant sought security for costs from him. ${ }^{88}$ In another Part IVA action, one of the two class representatives resided in Nauru. The case was dismissed on the ground that the Federal Court of Australia was not a convenient forum for the trial of the proceeding. ${ }^{89}$

\section{THE MARITAL STATUS OF CLASS REPRESENTATIVES}

We were able to identify the marital status of 107 class representatives who were married, in a de facto relationship, (common law in North America) separated/divorced or widowed. This accounts for $31.56 \%$ of all the individuals who acted as class representatives.

Table 15: Marital status of class representatives

\begin{tabular}{|l|l|}
\hline Marital status & $\begin{array}{l}\text { Number of class } \\
\text { representatives }\end{array}$ \\
\hline Married & 90 \\
\hline In a de facto relationship & 6 \\
\hline Divorced/separated & 8 \\
\hline Widowed & 3 \\
\hline
\end{tabular}

Table 16: Registered marital status ${ }^{90}$ of persons in Australia (aged 15 years and over)

\begin{tabular}{|l|l|l|l|}
\hline & $\begin{array}{l}\text { \% of persons (1996 } \\
\text { census) }\end{array}$ & $\begin{array}{l}\text { \% of persons (2001 } \\
\text { census) }\end{array}$ & $\begin{array}{l}\text { \% of persons (2006 } \\
\text { census) }\end{array}$ \\
\hline Married & $53.3 \%$ & $51.4 \%$ & $49.6 \%$ \\
\hline Never married & $30.5 \%$ & $31.6 \%$ & $33.2 \%$ \\
\hline Separated or divorced & $9.8 \%$ & $10.8 \%$ & $11.3 \%$ \\
\hline Widowed & $6.4 \%$ & $6.2 \%$ & $5.9 \%$ \\
\hline
\end{tabular}

This case appears to confirm the accuracy of the following comment made by Justice J Forrest of the Supreme Court of Victoria in the context of considering, during a directions hearing in a Victorian class action, the replacement of a class representative who resided in Victoria with a person who resided in Switzerland: "in relation to giving instructions and the like it seems abundantly clear in this day and age ... that he can give instructions" (Transcript of Proceedings; Cohen, supra note 5; 21 March 2011) at 67.

Wong, supra note 15.

88 See Francey v Sharpe Development Group Pty Limited [2005] FCA 1059.

See Amwano v Parbery [2005] FCA 1804.

90 This variable identifies a person's formal registered marital status.

91 Australian Bureau of Statistics, 2001 Census QuickStats: Australia, (2006) Table: Marital Status. Australian Bureau of Statistics, 2006 Census QuickStats: Australia, (2007) Table: Marital Status. 
Table 17: Social marital status
over)

\begin{tabular}{|l|l|l|l|}
\hline & $\begin{array}{l}\text { \% of persons (1996 } \\
\text { census) }\end{array}$ & $\begin{array}{l}\text { \% of persons (2001 } \\
\text { census) }\end{array}$ & $\begin{array}{l}\text { \% of persons (2006 } \\
\text { census) }\end{array}$ \\
\hline $\begin{array}{l}\text { Married in a } \\
\text { registered marriage }\end{array}$ & $54.07 \%$ & $51.95 \%$ & $50.45 \%$ \\
\hline $\begin{array}{l}\text { Married in a de facto } \\
\text { marriage }\end{array}$ & $6.01 \%$ & $7.33 \%$ & $8.76 \%$ \\
\hline Not married & $39.92 \%$ & $40.72 \%$ & $40.79 \%$ \\
\hline
\end{tabular}

With respect to those class representatives, whose marital status we were able to determine, it is evident that a large majority of them were married. This appears to accord with overall trends in Australia. With regard to both registered marital status and social marital status, it is evident that marriage is the most common type of marital status in Australia.

The review of the data on Part IVA plaintiffs revealed an interesting trend regarding the marital status of class representatives, namely, the significant number of married couples who acted as class representatives in the same proceedings. We found twenty-seven married couples and two de facto couples who were simultaneously class representatives. This means that a total of 58 $(17 \%)$ of all the class representatives who were natural persons co-represented the class with their spouse or de facto partner. It is also fascinating to note the following matters: (a) none of these 29 couples were same-sex couples; ${ }^{96}$ (b) the name of the female class representative appeared before the name of her partner in the pleadings filed with respect to the class actions brought by the two de facto couples; and (c) the wife's name preceded the husband's name in the pleadings in only two of the 27 instances of married couples acting as class representatives.

One of the main reasons behind the prominence of married or de facto couples, sharing the role of representing classes of similarly situated claimants, stems from the not uncommon scenario of each spouse or partner sharing the same occupation or running a small business together. The most common instance of a couple sharing the same occupation occurred when each spouse was a farmer. This occurred in five proceedings. Another scenario which led to each spouse/partner having claims in the proceeding occurred when a couple had joint ownership of an asset or had been jointly involved in an investment, and there was a claim in relation to that asset/investment. Also interesting to note is the number of parents

92 This variable identifies a person's relationship status based on their current living arrangements.

94 Australian Bureau of Statistics, 2006 Census Community Profile Series: Time Series Profile, Table 05A and 05B; 'Social Marital Status by Age by Sex for Time Series (Cat. No. 2003.0, 2007).

95 It includes data on same-sex couples.

96 Conversely, with respect to the Australian community, the Australian Study of Health and Relationships estimated that $2.2 \%$ of all couples living in the same household and aged 16-59 are same-sex couples: D de Vaus; Australian Institute of Family Studies, Diversity and Change in Australian Families: Statistical Profiles (2004), at 83, online: Australian Institute of Family Studies <http://www.aifs.gov.au/ins-titute/pubs/diversity/07samesex.pdf>. 
and children who acted as class representatives in the same litigation. We discovered six instances of a parent and his/her child representing class members in the same Part IVA proceeding.

\section{THE EMPLOYMENT STATUS OF CLASS REPRESENTATIVES}

The employment status of 238 (or over 70\%) of all the individuals, who represented class members in Part IVA proceedings, was ascertained.

\section{A. Unemployed class representatives}

Just over $32.35 \%$ (or 77) of these 238 class representatives were not in paid employment at the time that they commenced their duties as class representatives. The reasons for this status are summarised below.

\section{Table 18: Reasons why class representatives were not employed}

\begin{tabular}{|l|l|}
\hline Reason & Total number of class representatives \\
\hline Retired & 31 \\
\hline In prison/mandatory detention & 13 \\
\hline Did home duties & 5 \\
\hline Unable to find work & 2 \\
\hline Had a disability/illness & 8 \\
\hline Student & 5 \\
\hline Prohibited from working in Australia & 11 \\
\hline Unknown & 2 \\
\hline Total & $\mathbf{7 7}$ \\
\hline
\end{tabular}

In numerous cases, however, it was evident that the entire class represented in the proceeding was not in paid employment at the commencement of the litigation. Therefore, whoever chose (or was invited) to lead the class was not going to be employed at the time that they commenced as class representatives. For example, in at least seven migration cases each member of the class was being held mandatorily in a detention centre. Another Part IVA proceeding was brought on behalf of Aboriginal persons who were serving sentences of imprisonment in, or were facing imprisonment in, New South Wales prisons. ${ }^{97}$ It was therefore inevitable that the representatives of these classes of claimants were unemployed at the time the proceeding was filed.

The table below lists the reasons why class representatives were not employed, at the time that they assumed a representative role, but only in those Part IVA proceedings which featured a class which comprised both employed and unemployed persons.

\section{Table 19: Reasons why class representatives were not employed ${ }^{98}$}

97 We found only one other instance of a class representative with a criminal record. This was in an industrial class action and the class representative in question had a criminal conviction for unlawful use of a motor vehicle. He also had charges pending against him for malicious damage to a motor vehicle for a road rage incident.

In cases where the classes comprised both employed and unemployed class members. 


\begin{tabular}{|l|l|}
\hline Reason & Total number of class representatives \\
\hline Retired & 16 \\
\hline In prison/mandatory detention & 0 \\
\hline Home duties & 4 \\
\hline Unable to find work & 2 \\
\hline Had a disability/illness & 8 \\
\hline Student & 5 \\
\hline Prohibited from working in Australia & 1 \\
\hline Unknown & 2 \\
\hline Total & $\mathbf{3 8}$ \\
\hline
\end{tabular}

It is therefore plain that, out of a total of seventy-seven class representatives who were unemployed, only thirty-eight of them were members of a class which contained both employed and unemployed claimants. The fact that only thirtyeight individuals - who were selected from a class that comprised both employed and unemployed persons - were not in paid employment when they commenced their representative duties does not support the existence of a strategy that entails the frequent and deliberate appointment of persons of straw as class representatives. This conclusion is strengthened by the finding that 7 (close to $20 \%$ ) of these 38 unemployed class representatives came from class actions funded by litigation funders. Thus, the strategy of preventing defendants from recouping some of their costs would have been pointless in these funded proceedings. Furthermore, the overall data referred to in the next paragraph demonstrates that a clear majority of the class representatives $(67.65 \%)$ - whose employment status we were able to determine - were in paid employment (and were thus receiving income) when they decided to represent Part IVA class members. These occupations are examined below.

\section{B. Employed class representatives}

We discovered that 161 class representatives were employed at the time that they commenced as class representatives. We have coded the occupations of all employed class representatives using the classification contained in the Australian and New Zealand Standard Classification of Occupations [ANZSCO]. ${ }^{99}$ This data is contained in Table 20 below.

99 Dennis Trewin, Brian Pink \& Australian Bureau of Statistics, Statistics New Zealand, ANZSCO Australian and New Zealand Standard Classification of Occupations, First Edition (Cat No. 1220.0, 2006), online: ABS

<http://www.ausstats.abs.gov.au/ausstats/subscriber.nsf/0/69651C2DD21FE15BCA-

2575DF001CB1CC/\$File/12200_2006.pdf> [ANZSCO First Edition]. Brian Pink \& Geoff

Bascand" Australian Bureau of Statistics, Statistics New Zealand, ANZSCO - Australian and New Zealand Standard Classification of Occupations, First Edition, Revision 1 (Cat No. 1220.0;

2009), online: ABS <http://www.ausstats.abs.gov.au/ausstats/subscriber.nsf/0/DF6EC104F9730-

D3ECA2575DF001CB71D/\$File/12200_first\%20edition\%20revision\%201.pdf>. 
Table 20: Occupations of all employed class representatives

\begin{tabular}{|l|l|l|}
\hline Occupation & Number of class representatives & $\begin{array}{l}\text { \% of employed class } \\
\text { representatives }\end{array}$ \\
\hline Professionals & 55 & $34.2 \%$ \\
\hline $\begin{array}{l}\text { Clerical and administrative } \\
\text { workers }\end{array}$ & 5 & $3.1 \%$ \\
\hline $\begin{array}{l}\text { Technicians and trades } \\
\text { workers }\end{array}$ & 8 & $5.0 \%$ \\
\hline Managers & 39 & $24.2 \%$ \\
\hline Labourers & 17 & $10.6 \%$ \\
\hline Sales workers & 2 & $1.2 \%$ \\
\hline $\begin{array}{l}\text { Community and personal } \\
\text { service workers }\end{array}$ & 26 & $16.1 \%$ \\
\hline $\begin{array}{l}\text { Machinery operators and } \\
\text { drivers }\end{array}$ & 9 & $5.6 \%$ \\
\hline
\end{tabular}

Table 21 includes the occupations of class representatives only with respect to those Part IVA proceedings where the nature of the substantive claims, which were advanced in the litigation, did not dictate that the class representatives had to be members of a given profession, field or sector. An example of a Part IVA proceeding where the class representatives came perforce from a particular occupation is furnished by the action that was filed on behalf of all the Deputy Registrars of the Family Court of Australia with respect to an industrial dispute with the Court. ${ }^{100}$ The fact that the class comprised Deputy Registrars only meant, of course, that the class representatives had to be Deputy Registrars.

\section{Table 21: Occupations of employed class representatives ${ }^{101}$}

\begin{tabular}{|l|l|l|}
\hline Occupation & $\begin{array}{l}\text { Number of class } \\
\text { representatives }\end{array}$ & $\begin{array}{l}\text { \% of employed class } \\
\text { representatives }\end{array}$ \\
\hline Professionals & 34 & $48.6 \%$ \\
\hline $\begin{array}{l}\text { Clerical and administrative } \\
\text { workers }\end{array}$ & 4 & $5.7 \%$ \\
\hline $\begin{array}{l}\text { Technicians and trades } \\
\text { workers }\end{array}$ & 5 & $7.1 \%$ \\
\hline Managers & 13 & $18.6 \%$ \\
\hline Labourers & 11 & $15.7 \%$ \\
\hline Sales workers & 2 & $2.9 \%$ \\
\hline $\begin{array}{l}\text { Community and personal } \\
\text { service workers }\end{array}$ & 0 & $0 \%$ \\
\hline $\begin{array}{l}\text { Machinery operators and } \\
\text { drivers }\end{array}$ & 1 & $1.4 \%$ \\
\hline
\end{tabular}

100 CPSU, The Community and Public Sector Union v Commonwealth of Australia [1999] FCA 653.

101 As noted above, this table contains data with respect to those Part IVA proceedings where the nature of the substantive claims, which were advanced in the litigation, did not dictate that the class representatives had to be members of a given profession, field or sector. 
Table 22: Occupations ${ }^{102}$ of persons in Australia ${ }^{103}$ (aged 15 years and over) ${ }^{104}$

\begin{tabular}{|l|l|l|l|}
\hline Occupation & $\begin{array}{l}\text { \% of employed } \\
\text { persons aged 15 } \\
\text { years and over } \mathbf{1 9 9 6} \\
\text { census) }\end{array}$ & $\begin{array}{l}\text { \% of employed persons } \\
\text { aged 15 years and over } \\
\mathbf{2 0 0 1} \text { census) }\end{array}$ & $\begin{array}{l}\text { \% of employed } \\
\text { persons aged 15 years } \\
\text { and over } \\
\text { (2006 census) }\end{array}$ \\
\hline Professionals & $17.39 \%$ & $18.71 \%$ & $19.84 \%$ \\
\hline $\begin{array}{l}\text { Clerical and } \\
\text { administrative } \\
\text { workers }\end{array}$ & $15.89 \%$ & $15.56 \%$ & $15 \%$ \\
\hline $\begin{array}{l}\text { Technicians and } \\
\text { trades workers }\end{array}$ & $15.22 \%$ & $14.41 \%$ & $14.38 \%$ \\
\hline Managers & $13.63 \%$ & $13.32 \%$ & $13.21 \%$ \\
\hline Labourers & $10.2 \%$ & $10.24 \%$ & $10.46 \%$ \\
\hline Sales workers & $9.45 \%$ & $10.10 \%$ & $9.84 \%$ \\
\hline $\begin{array}{l}\text { Community and } \\
\text { personal service } \\
\text { workers }\end{array}$ & $7.6 \%$ & $8.24 \%$ & $8.81 \%$ \\
\hline $\begin{array}{l}\text { Machinery } \\
\text { operators and } \\
\text { drivers }\end{array}$ & $7.99 \%$ & $7.4 \%$ & $6.64 \%$ \\
\hline $\begin{array}{l}\text { Inadequately } \\
\text { described/ Not } \\
\text { stated }\end{array}$ & $2.62 \%$ & $2.02 \%$ & $1.82 \%$ \\
\hline
\end{tabular}

As can be seen from Tables 20 and 21, class representatives came from "all walks of life". A variety of occupations were held by class representatives at the time that they assumed that responsibility. However, where the nature of the substantive claims did not dictate that the class representatives had to be members of a given profession, field or sector, it is evident that professionals overwhelmingly provided the greatest number of class representatives. The proportion of professionals who were class representatives $(48.6 \%)$ is evidently much higher than the national percentage of people in this occupation in 1996, 2001 and 2006 $(17.39 \%, 18.71 \%$ and $19.84 \%$, respectively), although it was the most common occupation in Australia during these years. Managers were the second most common occupation of class representatives (18.6\%).

The high number of professionals and managers who assumed the role of class representatives further contradicts "the deliberate appointment of persons of straw" theory. Professionals and managers often have a high skill level, with a degree, diploma and several years of relevant experience. ${ }^{106}$ As a consequence, they often earn significant amounts. Therefore, they can hardly be regarded as

102 "Occupation" was coded to the 2006 Australian and New Zealand Standard Classification of Occupations [ANZSCO], supra note 98. This has replaced the 1996 Australian Standard Classification of Occupations (ASCO) Second Edition. Data for 1996 and 2001 have been concorded.

103 It excludes overseas visitors.

104 Australian Bureau of Statistics, 2006 Census Community Profile Series: Time Series Profile, Table 26: Occupation by Sex for Time Series (Cat. No. 2003.0, 2007).

105 In 1996 and 2001 "Technicians and trades workers" includes engineering, information and communications technology and science technicians and tradespersons.

106 Dennis Trewin, Brian Pink; Australian Bureau of Statistics, Statistics New Zealand, ANZSCO Australian and New Zealand Standard Classification of Occupations, First Edition (Cat. no. 1220.0 ; 2006) 70, 140. 
persons of straw. This is a significant finding when one also bears in mind that, as recently noted by Justice Cullity of the Ontario Superior Court of Justice, "in view of the legislative objective of providing access to justice to persons who would otherwise be deprived of it, plaintiffs are very often of limited means ...". ${ }^{107}$

\section{White collar and blue collar class representatives}

We have used the classification of white collar and blue collar workers employed by the ABS in their report, Australian Social Trends ${ }^{108}$ to categorise the occupations found in Australia. According to this classification, white collar workers include managers, professionals, community and personal service workers, clerical and administrative workers, and sales workers as defined in the ANZSCO $^{109}$ major occupation groups. ${ }^{110}$ Blue collar workers are those categorised in ANZSCO as technicians and trades workers, machinery operators and drivers, and labourers. ${ }^{111}$ Using this classification we have divided, in Table 23 below, the data set out in Table 22 into white collar and blue collar workers.

Table 23: White collar and blue collar workers in Australia

\begin{tabular}{|l|l|l|}
\hline Year & \% of white collar workers & \% of blue collar workers \\
\hline 1996 & $63.96 \%$ & $33.41 \%$ \\
\hline 2001 & $65.93 \%$ & $32.05 \%$ \\
\hline 2006 & $66.70 \%$ & $31.48 \%$ \\
\hline
\end{tabular}

Using the same classification, we have also divided the data on the occupations of class representatives contained in Table 21 into white collar and blue collar workers.

Table 24: White collar and blue collar class representatives

\begin{tabular}{|l|l|}
\hline \% of white collar workers & \% of blue collar workers \\
\hline $75.80 \%$ & $24.20 \%$ \\
\hline
\end{tabular}

As evidenced by Table 24, there were three white collar class representatives for every blue collar class representative. This should be contrasted with the 2 to 1 ratio of white collar workers to blue collar workers in Australia's general population (as revealed by Table 23). This disproportionate percentage of white collar workers can be attributed to the data revealed above, namely, the high number of class representatives who were professionals or managers.

107 Attis, supra note 36 at para 6.

Brian Pink; Australian Bureau of Statistics, Australian Social Trends: Using statistics to paint a picture of Australian Society, June 2011 (Cat. No. 4102.0, 2011) 7, online: ABS $<$ http://www.ausstats.abs.gov.au/ausstats/subscriber.nsf/0/02ED689E02C6CF39CA257960000D5D50/\$File/41020_astjun2011.pdf> [Australian Social Trends].

109 ANZSCO First Edition, supra note 106

110 Australian Social Trends, supra note 108.

111 Ibid 


\section{Industry of Employment}

We have coded the industry of employment of employed class representatives using the Australian and New Zealand Standard Industrial Classification. ${ }^{112}$ The table below identifies the main industries of employment for the employed class representatives aged over 15 who were involved in Part IVA proceedings, where the nature of the claim did not dictate the profession, field or sector of the class representative.

Table 25: Industry of employment for class representatives

\begin{tabular}{|l|l|}
\hline Industry & Number and \% of class representatives \\
\hline Agriculture, forestry \& fishing & $2(2.86 \%)$ \\
\hline Mining & $0(0.00 \%)$ \\
\hline Manufacturing & $9(12.86 \%)$ \\
\hline Electricity, gas, water \& waste services & $0(0.00 \%)$ \\
\hline Construction & $4(5.71 \%)$ \\
\hline Wholesale trade & $0(0.00 \%)$ \\
\hline Retail trade & $2(2.86 \%)$ \\
\hline Accommodation \& food services & $2(2.86 \%)$ \\
\hline Transport, postal \& warehousing & $2(2.86 \%)$ \\
\hline Information media \& telecommunications & $3(4.29 \%)$ \\
\hline Financial \& insurance services & $11(15.71 \%)$ \\
\hline Rental, hiring \& real estate services & $0(0.00 \%)$ \\
\hline Professional, scientific \& technical services & $4(5.71 \%)$ \\
\hline Administrative \& support services & $0(0.00 \%)$ \\
\hline Public administration \& safety & $4(5.71 \%)$ \\
\hline Education \& training & $4(5.71 \%)$ \\
\hline Health care \& social assistance & $10(14.29 \%)$ \\
\hline Arts \& recreation services & $2(2.86 \%)$ \\
\hline Other services & $6(8.57 \%)$ \\
\hline Unknown & $5(7.14 \%)$ \\
\hline
\end{tabular}

Table 26: Industry of employment ${ }^{113}$ of persons in Australia $^{114}$ (aged 15 years and over) ${ }^{115}$

\begin{tabular}{|l|l|l|l|}
\hline Industry & $\begin{array}{l}\text { Total persons } \\
(\mathbf{1 9 9 6} \text { census })\end{array}$ & $\begin{array}{l}\text { Total persons } \\
\mathbf{( 2 0 0 1} \text { census })\end{array}$ & $\begin{array}{l}\text { Total persons } \\
(\mathbf{2 0 0 6} \text { census })\end{array}$ \\
\hline Agriculture, forestry \& fishing & $324,330(4.25 \%)$ & $330,782(3.98 \%)$ & $280,918(3.09 \%)$ \\
\hline Mining & $86,261(1.13 \%)$ & $75,178(0.90 \%)$ & $106,894(1.17 \%)$ \\
\hline
\end{tabular}

112 Dennis Trewin \& Brian Pink; Australian Bureau of Statistics, Statistics New Zealand, Australian and New Zealand Standard Industrial Classification 2006 (Cat. No. 1292.0, 2006), online: ABS $<$ http://www.aus-

stats.abs.gov.au/ausstats/subscriber.nsf/0/10AD7A6DDB4190BFCA257122001ACD9E/\$File/12 920_2006.pdf>. Dennis Trewin \& Brian Pink; \& Australian Bureau of Statistics, Statistics New Zealand, Australian and New Zealand Standard Industrial Classification 2006 (Revision 1.0) (Cat. No. 1292.0; 2008), online: ABS<http://www.ausstats.abs.gov.au/ausstats/subscriber.nsf/0/19C21C5659BCAE73CA2574C80 01474E4/\$File/12920_2006\%20(revision\%201).pdf>.

113 Industry of employment was coded to the 2006 Australian and New Zealand Standard Industrial Classification (ANZSIC) edition. This has replaced the 1993 ANZSIC edition. Data for 1996 and 2001 have been concorded. Ibid.

114 The data contained in this table excludes overseas visitors.

115 Australian Bureau of Statistics, 2006 Census Community Profile Series: Time Series Profile, Table 25: Industry of Employment by Sex for Time Series (Cat. No. 2003.0, 2007). 


\begin{tabular}{|c|c|c|c|}
\hline Manufacturing & $922,899(12.09 \%)$ & $980,950(11.82 \%)$ & $952,015(10.46 \%)$ \\
\hline $\begin{array}{l}\text { Electricity, gas, water \& waste } \\
\text { services }\end{array}$ & $69,441(0.91 \%)$ & $77,030(0.93 \%)$ & $89,451(0.98 \%)$ \\
\hline Construction & $471,135(6.17 \%)$ & $543,239(6.55 \%)$ & $709,843(7.80 \%)$ \\
\hline Wholesale trade & $422,683(5.54 \%)$ & $417,928(5.04 \%)$ & $396,368(4.35 \%)$ \\
\hline Retail trade & $778,005(10.19 \%)$ & $922,567(11.12 \%)$ & $\begin{array}{l}1,033,191 \\
(11.35 \%)\end{array}$ \\
\hline Accommodation \& food services & $476,672(6.24 \%)$ & $540,681(6.51 \%)$ & $575,111(6.32 \%)$ \\
\hline Transport, postal \& warehousing & $359,157(4.70 \%)$ & $385,270(4.64 \%)$ & $427,789(4.70 \%)$ \\
\hline $\begin{array}{l}\text { Information media } \quad \& \\
\text { telecommunications }\end{array}$ & $192,914(2.53 \%)$ & $204,280(2.46 \%)$ & $176,823(1.94 \%)$ \\
\hline Financial \& insurance services & $296,456(3.88 \%)$ & $312,396(3.76 \%)$ & $348,586(3.83 \%)$ \\
\hline $\begin{array}{l}\begin{array}{l}\text { Rental, hiring \& real estate } \\
\text { services }\end{array} \\
\end{array}$ & $118,554(1.55 \%)$ & $141,055(1.70 \%)$ & $153,907(1.69 \%)$ \\
\hline $\begin{array}{l}\text { Professional, scientific } \quad \& \\
\text { technical services }\end{array}$ & $467,170(6.12 \%)$ & $548,491(6.61 \%)$ & $602,017(6.61 \%)$ \\
\hline Administrative \& support services & $211,736(2.77 \%)$ & $276,534(3.33 \%)$ & $286,622(3.15 \%)$ \\
\hline Public administration \& safety & $466,527(6.11 \%)$ & $483,690(5.83 \%)$ & $608,605(6.68 \%)$ \\
\hline Education \& training & $559,212(7.32 \%)$ & $626,966(7.56 \%)$ & $697,805(7.66 \%)$ \\
\hline Health care \& social assistance & $716,163(9.38 \%)$ & $793,391(9.56 \%)$ & $956,144(10.5 \%)$ \\
\hline Arts \& recreation services & $107,691(1.41 \%)$ & $115,024(1.39 \%)$ & $127,396(1.40 \%)$ \\
\hline Other services & $334,432(4.38 \%)$ & $330,635(3.98 \%)$ & $338,212(3.71 \%)$ \\
\hline Inadequately described/Not stated & $254,881(3.34 \%)$ & $192,519(2.32 \%)$ & $236,487(2.60 \%)$ \\
\hline Total & $7,636,319$ & $8,298,606$ & $9,104,184$ \\
\hline
\end{tabular}

As is evident from Table 25, the occupational industries in which class representatives were employed were quite diverse. The most common industry however was the financial and insurance services industry. As can be seen from Table 26, the financial and insurance industry is not an extremely popular industry in Australia. In fact, it was the thirteenth most common industry in 1996 and the eleventh most common industry in 2006.

A reason for the higher proportion of class representatives working in the financial and insurance industries may be due to the nature of the claims advanced in the Part IVA proceedings which were filed in the study period. There were (as the data contained in Table 3 above showed) numerous class actions which centred on financially related claims such as investments and shares. There is perhaps a higher likelihood that people who are employed in this industry will be involved in these types of claims due to their knowledge and expertise of the subject matter, and subsequently are more likely to become class representatives in a class action centred on these claims. In this context, it is important to note that in Canada the fact that a proposed class representative had expertise in the area/subject matter with respect to which the class action was filed has been regarded as a factor supporting a judicial finding that the class representative in question will adequately represent the interests of class members. ${ }^{116}$ Conversely, the retail trade, which was the most common industry in Australia in 2006, was not an industry in

116 For a very recent illustration, see Simmonds v Armtec Infrastructure Inc [2012] OJ No 277 at para 74 , Thomas J (ONSC) where in a class action concerning alleged misrepresentations contained in a prospectus, the trial judge noted that the proposed class representatives brought to the proceeding "significant business acumen. They have held high-level positions in public and private companies and are experienced in the corporate responsibilities attached to public offerings. Their experience will not only benefit the class but it is important to recognize that they will be an easily accessed resource for plaintiffs' counsel ...". 
which most class representatives worked. In fact, only two class representatives worked in that industry.

\section{CLASS REPRESENTATIVES WITH A DISABILITY}

Seven class representatives, who had a disability whilst they were representing the class, were identified. These class representatives were the recipients of a disability/invalid pension. They account for over $2 \%$ of all the individuals who represented Part IVA classes.

According to the ABS, in $199819 \%$ of the Australian population had a reported disability. ${ }^{117}$ This figure slightly increased in 2003 , with $20 \%$ of the total population having a disability. ${ }^{118}$ In 2009 it was recorded that $18.5 \%$ of Australians had a reported disability. ${ }^{119}$

There is an obviously large disparity between the proportion of class representatives we were able to identify as disabled and the number of people with a disability in the Australian community. This may be attributable to a number of factors. Firstly, in some proceedings a class representative with a disability may not have been identifiable through the information we had at our disposal. There may have been many occasions where a disability of a class representative was not reported in a court file or media report simply because it did not have any bearing on the case. The low number of class representatives we identified as having a disability could also be due to the fact that perhaps people with a disability may be more reluctant to become class representatives. The role is likely to entail travelling for various reasons such as seeing their lawyers, ${ }^{120}$ attending directions hearings ${ }^{121}$ and mediation conferences and giving evidence during the trial; ${ }^{122}$ activities which would be fairly challenging for someone with a physical disability. The emphasis placed by leading plaintiff lawyers on the physical and psychological wellbeing of class representatives also suggests that plaintiff lawyers may prefer to have class representatives that do not carry a disability.

117 Dennis Trewin; Australian Bureau of Statistics, 2003 Year Book Australia (Cat. No. 1301.0, 2003) 258, online: ABS <http://www.ausstats.abs.gov.au/Ausstats/subscriber.nsf/0/03B93A4654A2D371CA256CB-70081FBE6/\$File/13010_2003.pdf>.

118 Australian Bureau of Statistics, Disability, Ageing and Carers, Australia: Summary of Findings (Cat. No. 4430.0, 2010) 3, online: ABS<http://www.ausstats.abs.gov.au/Ausstats/subscriber.nsf/0/9C2B94626-F0FAC62CA2577FA0011C431/\$File/44300_2009.pdf>.

119 Ibid.

120 As noted by the British Columbia Court of Appeal, the duties of class representatives encompass "attendance for examination in discovery, providing instructions on all steps taken in the litigation ...": Parsons, supra note 64.

121 The very limited data contained in the court files and the attendance of the authors at various directions hearings would tend to suggest that, more often than not, class representatives (and some class members) attend mediation conferences and the more important of the directions hearings, such as settlement hearings.

122 See e.g. A Lampe, “A Small Win for Investors” Sydney Morning Herald (14 July 2004) 9: "[the class representative], who endured days of cross-examination by a raft of counsel for the various defendants, said she was relieved that the case had been settled and that she could get on with her life". 


\section{CONCLUSION}

As colourfully noted in 2002 by French CJ, the current Chief Justice of the High Court of Australia when as a Federal Court justice he presided over a Part IVA proceeding; class representatives are the persons that are "prepared to, as it were, stick their head on the chopping block". ${ }^{123}$ They are the persons who step forward to represent often innumerable class members. They accept the responsibility of heading the claim when they could easily just be class members and potentially receive the same benefits of a successful claim without suffering (in class actions not supported by litigation funders) the financial consequences of a loss. As noted by the High Court of Australia:

In general, it is they [the class representatives] who may appeal and who are liable in costs. They stand to gain from any benefit obtained by the proceeding but they are at risk of bearing the burden of costs. The position of [representative plaintiffs] in the proceeding may be contrasted with those whom they represent the group members. ... Group members [instead] need take no positive step in the prosecution of the proceeding to judgment to gain whatever benefit its prosecution may bring.

The aim of this article was to shed some light on some of the fundamental characteristics of these important players by canvassing our empirical findings with respect to those individuals and entities that assumed the role of class representatives in class actions filed in the Federal Court of Australia over a period of 17 years. Through this investigation, we identified a number of personal characteristics of the "typical" class representative in such class actions. This typical class representative was male, middle aged, married and resided in New South Wales. He was also a professional, working in the financial and insurance services industry. He had no disabilities and no criminal record.

We have also compared this typical class representative with the "typical/average" Australian, as revealed by data collected by the Australian Bureau of Statistics. We revealed that the 2 to 1 ratio of men to women that we discovered in class action litigation was not matched in the broader Australian community as there were slightly more females living in Australian than there were males. But this male domination in class action litigation did mirror the broader Australian community when account was taken of the fact that men hold the majority of positions of power and leadership across all sectors of the Australian community. It was also discovered that class representatives tend to be older than individuals in the wider community but that the marital status of class representatives was largely consistent with overall trends in Australia. A major difference that was, however, detected in this latter area was the apparent lack of same-sex couples among class representatives. Other differences were identified as a result of the far greater presence, among class representatives vis-à-vis the

123 Transcript of Proceedings (Revian v Dasford Holdings Pty Ltd; 6 August 2002; French J), 17 [unpublished]. See also Sino-Forest Corp, supra note 39 at para 287 ("fellow class members ... at the end of the day want results not empathy from their representative plaintiff and class counsel"). 
general community, of white collar workers, professionals, managers and members of the financial and insurance services industry. 